\title{
Historical and Future Climatic Change Scenarios for Temperature and Rainfall for Iraq
}

\author{
Saleh Zakaria ${ }^{1,2}$, Nadhir Al-Ansari ${ }^{1}$ and Seven Knutsson ${ }^{1}$ \\ 1. Department of Civil, Environmental and Natural Resources Engineering, Lulea University of Technology, Lulea 971 87, Sweden \\ 2. Department of Water Resources Engineering, University of Mosul, Mosul 41002, Iraq
}

\begin{abstract}
The world is facing a big challenge of climatic change, mainly due to increasing concentrations of GHGs (greenhouse gases) in the atmosphere. Many researches indicated that the climate change occurred disproportionately on developing countries such as MENA (Middle East and North Africa) countries. The climatic model CGCM3.1 (T47) 2 is used in this research to explain the changes in average temperatures and the rainfall on the MENA region with special emphases on Iraq. Historical records (1900-2009) and future (2020-2099) were studied and compared; each period was divided to four sub-periods of thirty years. The results showed that the average monthly temperature for the four historical periods fluctuated between the lowest and highest value as follows: 9.2-32.9, 10.3-32.7, 9.3-32.8 and 8.6-33.9 $\left({ }^{\circ} \mathrm{C}\right)$. The rainfall for historical periods kept on the same distribution during the past 109 years, and fluctuated between the lowest and highest value of $21.3 \mathrm{~mm}$ and $37.6 \mathrm{~mm}$ with an average that reached up to $26.51 \mathrm{~mm}$. For the future period, the maximum average monthly temperature reached up to $37.41\left({ }^{\circ} \mathrm{C}\right)$ during June and minimum average monthly temperature reached up to $4.24\left({ }^{\circ} \mathrm{C}\right)$ during January. The average monthly temperature fluctuated giving a clear impression that the future portends a higher temperature. The average monthly rainfall, for the future period, fluctuated between the lowest and highest value of $12.91 \mathrm{~mm}$ and $20.63 \mathrm{~mm}$ with an average that reached $16.84 \mathrm{~mm}$ which represent a reduction percentage of about $36.47 \%$ relative to the historical record of rainfall for the same months.
\end{abstract}

Key words: Climatic change, MENA, climatic model CGCM3.1(T47) 2, Iraq.

\section{Introduction}

Climatic change is the biggest challenge facing the world. The change in the climatic system is mainly due to the increase in the concentration of GHGs (greenhouse gases) in the atmosphere. It is believed that the human activities are responsible for the increase of GHGs concentrations since the industrial revolution due to burning of fossil fuels like coal, oil and natural gas as an energy source.

The impact of climatic change may lead the world to face a serious risk of dust storms, droughts, floods and others events which may contribute to food shortages that inevitably will affect the sustainability of the communities, and their development.

Climatic change can cause significant impacts on

Corresponding author: Nadhir Al-Ansari, professor, research fields: water resources and environmental engineering. E-mail: nadhir.alansari@1tu.se. water resources and the hydrological cycle, where the change of the temperature and precipitation will affect the evapotranspiration process. Both, quality and quantity of the runoff component will suffer some changes which will lead to a significant effect on sectors like agriculture, industry and urban development [1].

The prevailing scientific convictions indicated that the global climate is changing due to human activities that are affecting three main factors: greenhouse gases, aerosols and land surface changes [2].

IPCC (intergovernmental panel on climatic change), in 2001 [3] defined the climatic change as "refers to a statistically significant variation in either the mean state of the climate or in its variability, persisting for an extended period (decades). Climatic change may be due to natural internal processes or external forcing or to persistent anthropogenic changes in the composition of the atmosphere or in land use". United Nations 
Framework Convention on Climatic Change in 1992 [4], defined the climatic change as "a change of climate which is attributed directly or indirectly to human activity that alters the composition of the global atmosphere and which is in addition to natural climatic variability observed over comparable time periods".

IPCC [5] reported that: the increased in mean annual global surface temperature, reached $0.74{ }^{\circ} \mathrm{C} \pm 0.18{ }^{\circ} \mathrm{C}$, most of the warming resulting from human activities that increase greenhouse gas in the atmosphere. According to the SRES (Special Report on Emission Scenarios) for greenhouse gas, the projections of the temperature at the end of the 21 st century range from $1.1{ }^{\circ} \mathrm{C}$ to $6.4{ }^{\circ} \mathrm{C}$, compared to end-20th century $[6,7]$.

IPCC [5] observed that there are different impacts on the physical and biological systems due to climatic change. The effect of changes in the global average temperature on global, regional and local levels such as: ecosystem health, food production, species distributions and phonology, human health, sea levels, precipitation and river runoff, drought, average and extreme changes in temperature and wind patterns. The impacts are, however, associated with large uncertainties. Recently, two main methods (adaptation and mitigation) followed concerning climatic changes.

The first is reducing greenhouse gas emissions, and the second is the adjustment in natural or human systems in response to actual or expected climatic stimuli [5].
Although the international community had identified the problem of climatic change, it did not succeed to limit the reasons that are leading to the continuation of climatic change especially the emission of greenhouse gases [8]. It is expected that the world will continue to face increase of the temperature that can reach up to more than 3 degrees Celsius by the end of this century, where the concentration of carbon dioxide has risen from 299.7 ppm (parts per million) in 1910 to 393.9 ppm in March 2012 [9].

The present work based on global climatic projections and scenarios inspired by national reports includes a review of the impact of climatic change on MENA (Middle East and North Africa) region, then it focuses on Iraq through the distribution of average monthly temperature and rainfall by historical (1990-2009) and future (2020-2100) scenarios according to the climatic change concept using the results of the Canadian model CGCM3.1(T47), Scenario A2.

\section{Study Area}

The MENA region consists of 25 countries covering an area of 14 million $\mathrm{km}^{2}$ and 358 million inhabitants $[10,11]$. The MENA land (Fig. 1) extends from the Atlantic Ocean in the west to the Arabian Sea in the east, and from the Mediterranean Sea in the north to the (Africa Horn) and the Indian Ocean in the southeast. Almost all of the MENA countries are located in

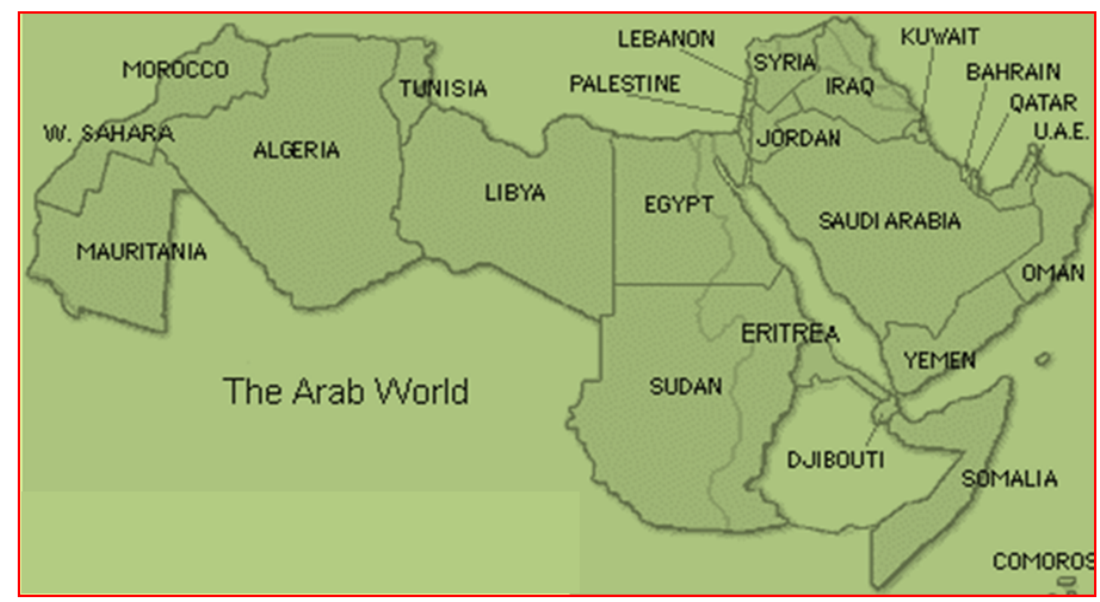

Fig. 1 Map of the MENA countries [14]. 
semi-arid and arid regions that are highly vulnerable to climatic change [12]. The annual rainfall at MENA countries is about 2,282 billion $\mathrm{m}^{3}$, while the annual surface water is about 205 billion $\mathrm{m}^{3}$ and the annual groundwater is about 35 billion $\mathrm{m}^{3}$ [13].

The annual rainfall distribution varies where $52 \%$ of the MENA countries receive an average of less than $100 \mathrm{~mm}$, while $15 \%$ receives between $100 \mathrm{~mm}$ to 300 $\mathrm{mm}$ and $18 \%$ receives more than $300 \mathrm{~mm}$. Some countries like Lebanon, Syria and North African countries and southern Sudan receive annual rainfall about $1,500 \mathrm{~mm}$.

MENA countries depend on agriculture and oil for their economy, therefore they are vulnerable to any climatic variations, as well as any mitigation policy aimed at reducing oil.

Iraq is one of the MENA countries located south west Asian, surrounded by Iran to the east, Turkey to the north, Syria and Jordan to the west, Saudi Arabia and Kuwait to the south, and the Gulf to the south-east.

Iraq extends between latitudes $29^{\circ} 5^{\prime}$ and $37^{\circ} 22^{\prime}$ north, and between longitudes $38^{\circ} 45^{\prime}$ and $48^{\circ} 45^{\prime}$ east.

The area of Iraq is about $435,052 \mathrm{~km}^{2}$. The total population of Iraq is about 20.4 million (1995), of which $25 \%$ in rural areas. Average population density is estimated to be 47 inhabitants $/ \mathrm{km}^{2}$ (it is about 5 inhabitants $/ \mathrm{km}^{2}$, in the desert at the western part of the country) to more than 170 inhabitants $/ \mathrm{km}^{2}$ in the Babylon province, in the center of the country [15].

Topographically, Iraq can be divided in four parts:

- Mesopotamian plain: Alluvial plain occupies a quarter of the area of Iraq or equivalent to 132,500 $\mathrm{km}^{2}$;

- Desert plateau: Located in the west of Iraq and occupies about less than half the size of Iraq or 168,552 $\mathrm{km}^{2}$;

- Mountainous region: Mountainous region is located the northern and the north-eastern part of Iraq and covers about $92,000 \mathrm{~km}^{2}$;

- Undulating region: A transition zone between the low-lying Mesopotamian plain in the south and the high mountains in the far north and the north-eastern Iraq and covers $67,000 \mathrm{~km}^{2}$.

Iraq lies within the northern temperate zone, but the climatic is continental and subtropical. Winters are usually cool to cold, with an average daily temperature that might reach $16{ }^{\circ} \mathrm{C}$ dropping at night to $2{ }^{\circ} \mathrm{C}$. Summers are dry and hot to extremely hot, with a shade temperature of over $43{ }^{\circ} \mathrm{C}$ during July and August, yet dropping at night to $26{ }^{\circ} \mathrm{C}$ [11]. The rainfall is tracking the climate of Mediterranean Sea. Fig. 2 shows Precipitation Map of Iraq, most of the rainfall falls during winter, spring and autumn. The rainfall is non-existent in the summer. Average annual rainfall is $154 \mathrm{~mm}$, and it ranges from less than $100 \mathrm{~mm}$ over $60 \%$ of the country in the south up to $1,200 \mathrm{~mm}$ in the north-east $[11,16]$. According to the rainfall classification of FAO documentation that was published in 2003 [17], Iraq can be divided into four agro-ecological zones as follow: (1) Summers prevail zone located at the northern governorates of Iraq; (2) Steppes zone has winter rainfall of $200-400 \mathrm{~mm}$ annually. This zone has extremely hot summer and cold winter, and covers the area located between the Mediterranean zone and the desert zone; (3) The desert zone having extreme summer temperatures and less than $200 \mathrm{~mm}$ of rainfall annually, and covers the area located between north of Baghdad to the Saudi Arabian and Jordanian borders; (4) The irrigated area, that extend between the Tigris and Euphrates Rivers, from north of Baghdad to Basra in the south [17, 19].

Three type of wind below on Iraq. The first is the northwest wind which blows during all seasons of the year. In winter, the wind is usually dry cold. While in the summer, it is smooth and leads to reduce the high temperatures. The second type of winds is the eastern or northeastern wind that below in winter and is accompanied by cold biting and clear sky. Third type of wind is the southeast wind that is relatively warm and moist and brings rainy clouds sometimes. 


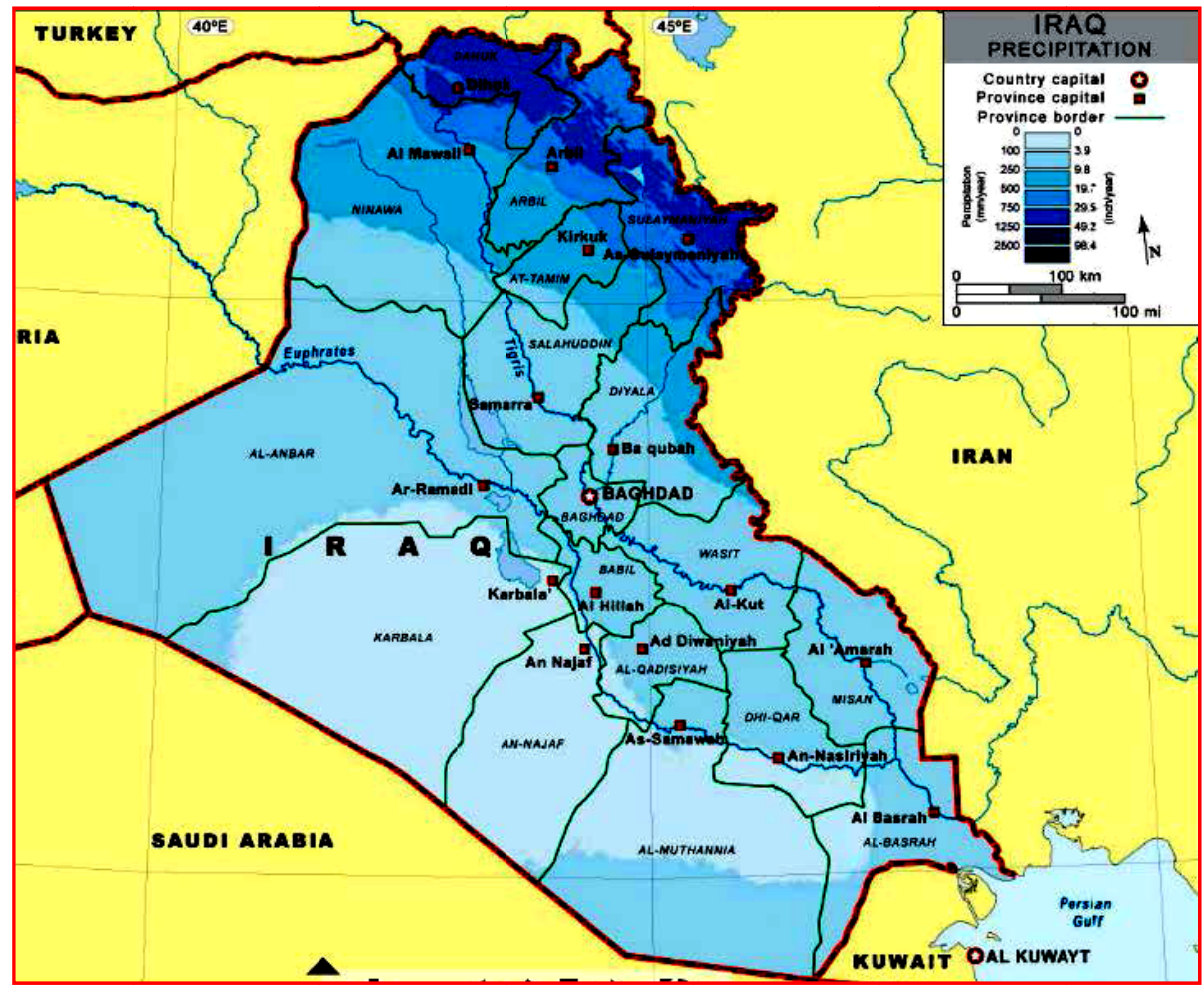

Fig. 2 Precipitation map of Iraq [18].

\section{Impact of Climatic Change on MENA Countries}

AFED (Arab Forum for Environment and Development) in 2009 reported that the MENA countries are in many ways among the most vulnerable in the world to the potential impacts of climatic change [20]. The most significant of which are increased average temperatures, less and more erratic precipitation, and SLR (sea level rise), in a region which already suffers from aridity, recurrent drought and water scarcity.

Haas [21], projected first order impacts of climatic change on Mediterranean hydrological systems and conclude that the impacts may induce an increase in evaporation from water and soils that reduce the available water supply.

Attaher et al. [22] studied the impact of climatic changes on ETO (evapotranspiration) in Egypt. The study indicated that projected future climatic changes will increase the potential irrigation demand in Egypt by $6-16 \%$ due to the increase in ETO by the 2100 s.

There is a big need for an integrated analysis that can determine the impact of climatic change on water resources and its components, such as precipitation, hydrologic regimes, drought, dam operations, etc. in the MENA region. This will help to identify the situation of local water resources and plan appropriate adaptation measures that should be taken in advance [23].

The Word Bank [24], stated that the MENA region is also affected by the increase of temperature due to the climatic changes. Five MENA countries, including Kuwait $\left(52.6{ }^{\circ} \mathrm{C}\right)$, Iraq $\left(52.0^{\circ} \mathrm{C}\right)$, Saudi Arabia $(52.0$ $\left.{ }^{\circ} \mathrm{C}\right)$, Qatar $\left(50.4{ }^{\circ} \mathrm{C}\right)$, and Sudan $\left(49.7^{\circ} \mathrm{C}\right)$ were among 19 countries that set new record highs in 2010.

The expected conditions in the MENA region as a result of the impact of climatic change are: (1) higher temperatures and intense heat waves, that effect lives and crops; (2) higher air temperatures leading to impacting marine ecosystems and fisheries; (3) less but more intense rainfall, causing both more droughts and 
greater flooding; (4) sea level rise; (5) more intense cyclones; (6) new areas exposed to dengue, malaria, and other vector and waterborne diseases; (7) increasing evidence shows that the climatic change has negative consequences on the social and economic development in the MENA countries [13].

In recent decades the most important features of the climatic in MENA region is the increase of temperature by $0.2-0.30^{\circ} \mathrm{C}$ per decade, rainfall is less, loss of winter precipitation, strong in snow mass including summer droughts. Future expectations are that the MENA region will be warmer, drier and more variable where the temperatures are likely to rise $0.3-0.40{ }^{\circ} \mathrm{C}$ per decade. This is 1.5 times faster than the global average. Most of North Africa and the eastern Mediterranean will become drier [24].

Al-Ani [25] analyzed a number of meteorological elements and variables for Iraq and surrounding areas, depending on the data given by European Centre for medium forecasts for the period 1979-1993. The results showed that the forecast process has a clear impact on the temperature and rainfall during the period of the forecast.

Jaber [26] studied the climatic change through a proposed climatic models and the impact of each model on the productivity of wheat and barley in Iraq.

Al-Obeidi [27] studied the effect of climatic extremism on the environment of the undulating region in Iraq for the period 1970-2000. The study aimed to build a climatic information base. The results showed that, three models for rainfall varied among semi-dry, moderate and wet.

AL-Bayati [28] studied the dust storms phenomena in middle and southern part of Iraq for the years (1981-2006) depending on five climatic stations that are located in the western desert area of Iraq. The study aimed to clarify the geographic distribution of the storms and the climatic factors that affect its distribution. The study showed that eleven factors has an effect on the frequency of this phenomenon. The most effective factor was relative humidity while the evaporation and clouds quantity were the least effective factors.

\subsection{The Impact of Climatic Change}

Recent studies indicated that greenhouse gases have a clear impact on climatic change. The negative impacts of climatic change may lead the world to face a serious risk that affect the life, health, the communities and development.

\subsection{Regional Distribution of GHGs Emissions}

IPCC [29] reported that the increase concentrations of GHGs play an important role in the climate change, gases such as carbon dioxide, methane, nitrous oxide and others. During the year of 2000, the total GHGs total GHGs emissions from the MENA countries that reached up to 325 , while the part that contributed by emissions from all resources of the world was about 33 thousand $\mathrm{Tg}$ (teragram) (Fig. 3), the part that contributed by MENA countries was about $4.2 \%$ of these total world emissions [30].

Fig. 4, shows that the KSA (Kingdom of Saudi Arabia) is contributing the highest percentage of the Iraq reached up to 100 [30].

The amount of GHGs gases that was emitted by the MENA countries represent a small proportion and does not correspond to the projected impacts of climatic change over the region [2].

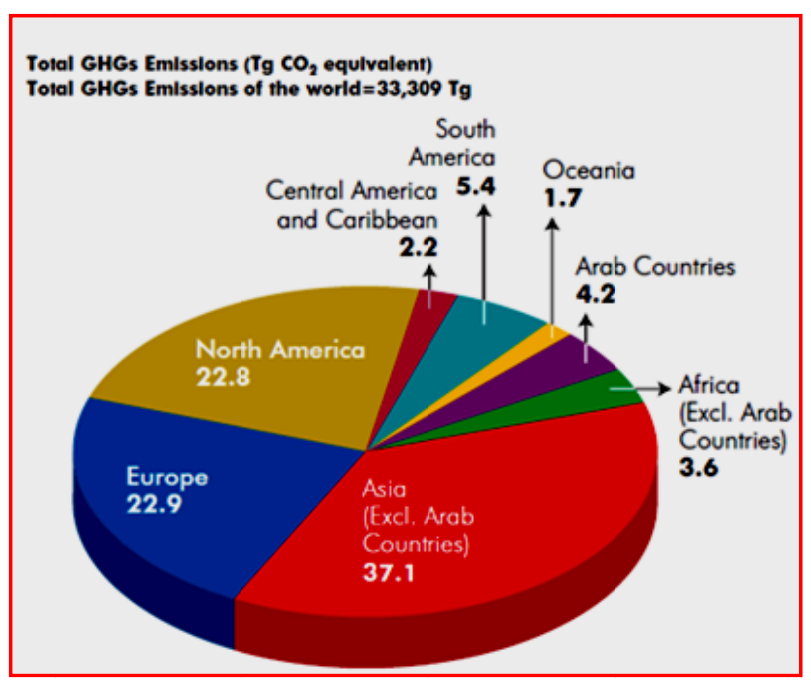

Fig. 3 Regional distribution of the GHGs emissions of the world through the year 2000 [30]. 
The MENA region is a wide area characterized by high degree of aridity where the annual rainfall is very low [31].

WRI [30] reported that the total global emissions grew $12.7 \%$ between 2000 and 2005, an average of $2.4 \%$ a year. However, individual sectors grew at rates between $40 \%$ and near zero, and there are substantial differences in scrotal growth rates between developed and developing countries. Emissions growth is produced from both developed and developing countries with different level. Certainly developed countries have the greatest share in emissions growth. Fig. 5 shows emissions growth by region in four select sectors: electricity and heat, transport, industry and building use.

MENA region is influenced by its geographical location that increases the impact of climatic change where most of the region is classified as hyper-arid, semi-arid and arid land zones (Fig. 6) [32]. Several researches confirmed the fact that arid and semi arid regions are highly vulnerable to climatic change [7].

IPCC [5] reported that the IPCC Special Report on Emissions Scenarios (SRES, 2000) projects an increase of global GHG emissions by $25 \%$ to $90 \%$ ( $\mathrm{CO}^{2}$-eq) between 2000 and 2030 (Fig. 7). It will be very likely that changes in the global climatic system will be larger

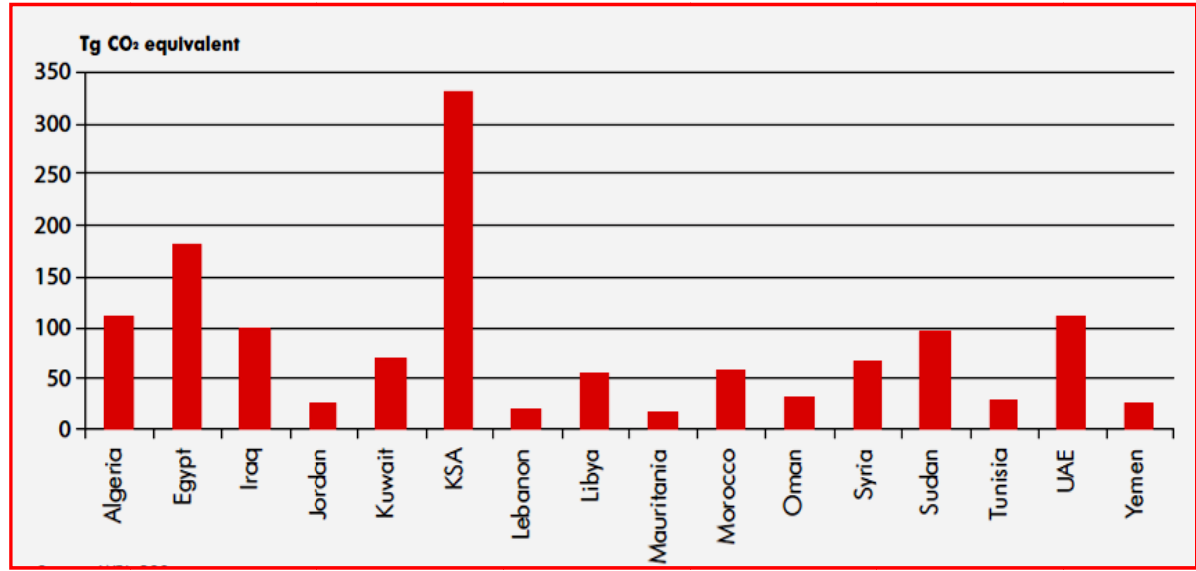

Fig. 4 MENA countries contributions of greenhouse gas emissions [30].

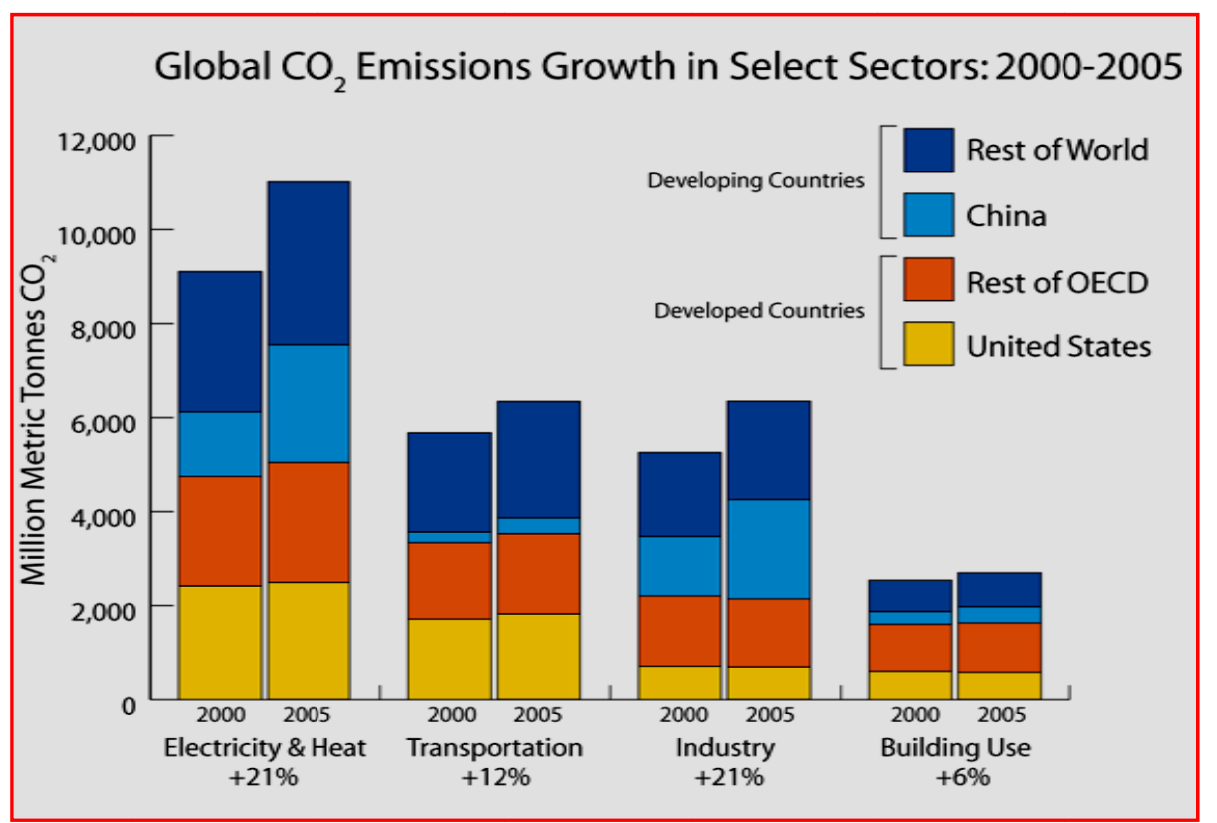

Fig. 5 Global $\mathrm{CO}_{2}$ emissions growth in select sectors: 2000-2005 [8]. 


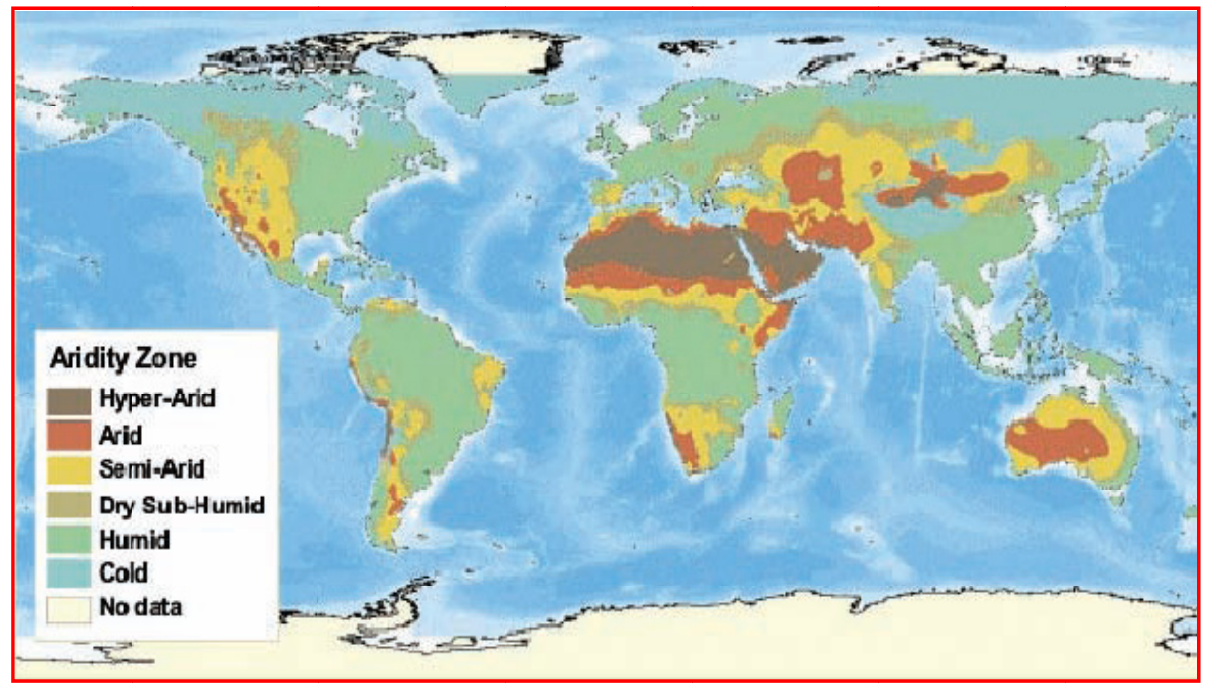

Fig. 6 Aridity zones of the world [32].
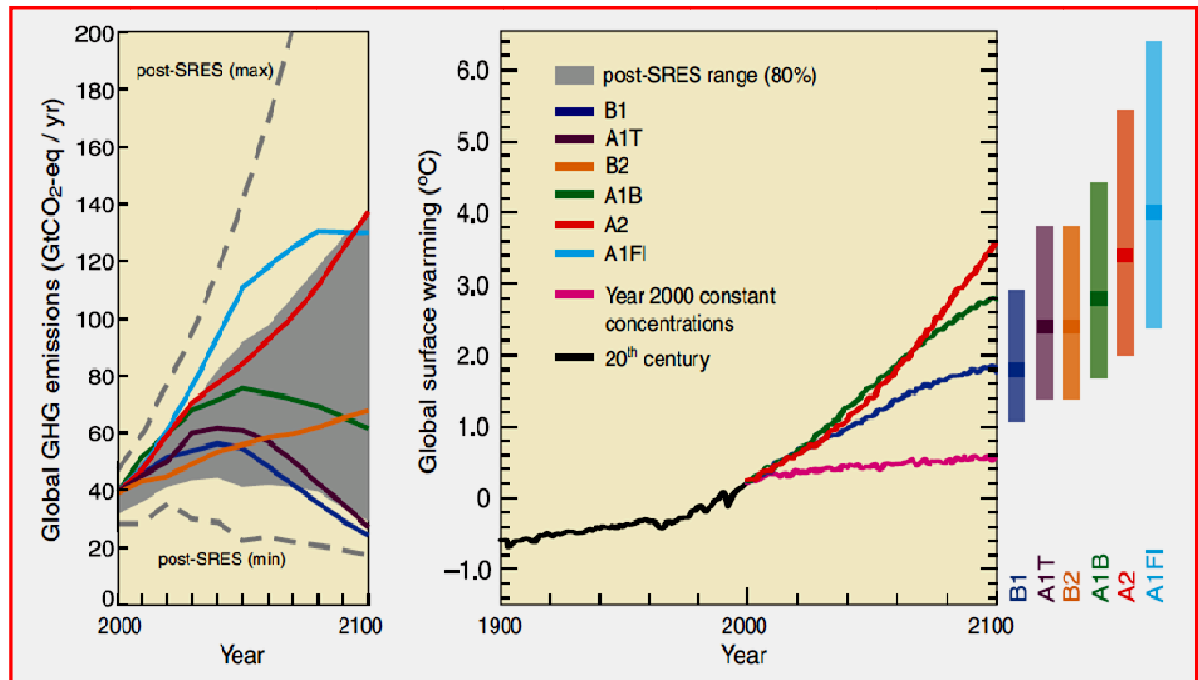

Fig. 7 Scenarios for GHG emissions from 2000 to 2100 (in the absence of additional climatic policies) and projections of surface temperatures [3].

during the 21 st century and warmer if GHG emissions continue at or above current rates.

\subsection{The Impact of Sea-Level Rise}

SLR (sea-level rise) is one obvious impact as a result of the climatic change. It is very likely that 20th century global warming has caused an increase of the size of seas and oceans, as well as loss of land ice [3]. Through the period 1961-2003, it was observed that the global sea level rise was about $1.8 \mathrm{~mm} /$ year while during the period 1993-2003 it reached up to $3.1 \mathrm{~mm}$ per year [5].
MENA countries are part of vulnerable countries to the impacts of SLR with different levels. Despite The fact that their coastlines will be under the impact of sea level rise, it will be more noticeable on countries that have deltaic areas, such as Egypt (Nile River delta) and Iraq (Tigris and Euphrates delta) (Fig. 8). These two areas are the most vulnerable in MENA countries by sea level rise [33].

AFED [20] reported that the Gulf is highly vulnerable at its northern tip north of Kuwait and south of Iraq (Shatt el-Arab) (Fig. 9). Despite the limited coastline of Iraq on the Gulf region, the vulnerable 
lowland areas extend as far inland as near Baghdad. The impact of SLR on the MENA countries was studied in a recent assessment by Dasgupta et al. [34]. In this assessment, the following six indicators were used: land, population, GDP (gross domestic product), urban extent, agricultural extent and wetlands. Finally, these impacts were calculated for SLR scenarios ranging from $1 \mathrm{~m}$ to $5 \mathrm{~m}$ (Table 1). Dasgupta et al. [34] concluded that Qatar's area would experience a significant reduction of about 2.6 to $13 \%$ due to $1 \mathrm{~m}$ and $5 \mathrm{~m}$ rises, respectively. One meter SLR will cause an impact on $10 \%$ of Egypt's population, more impact will be in the Nile Delta, it reaches a loss of $20 \%$ with a $5 \mathrm{~m}$ SLR. For United Arab Emirates and Tunisia, a SLR of $1 \mathrm{~m}$ would impact about $5 \%$ of the population.

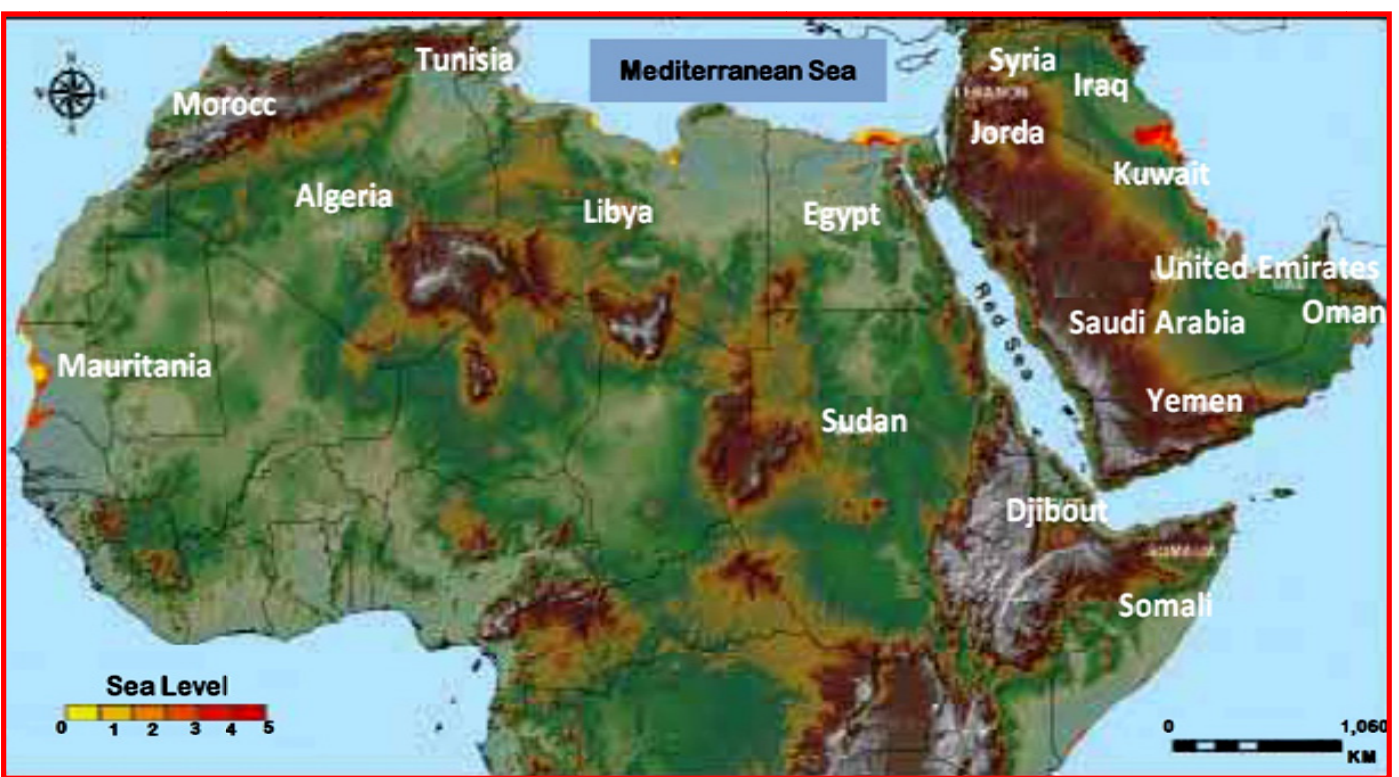

Fig. 8 The situation of the sea level rise for Egypt (Nile River delta) and Iraq (Tigris and Euphrates delta) [33].

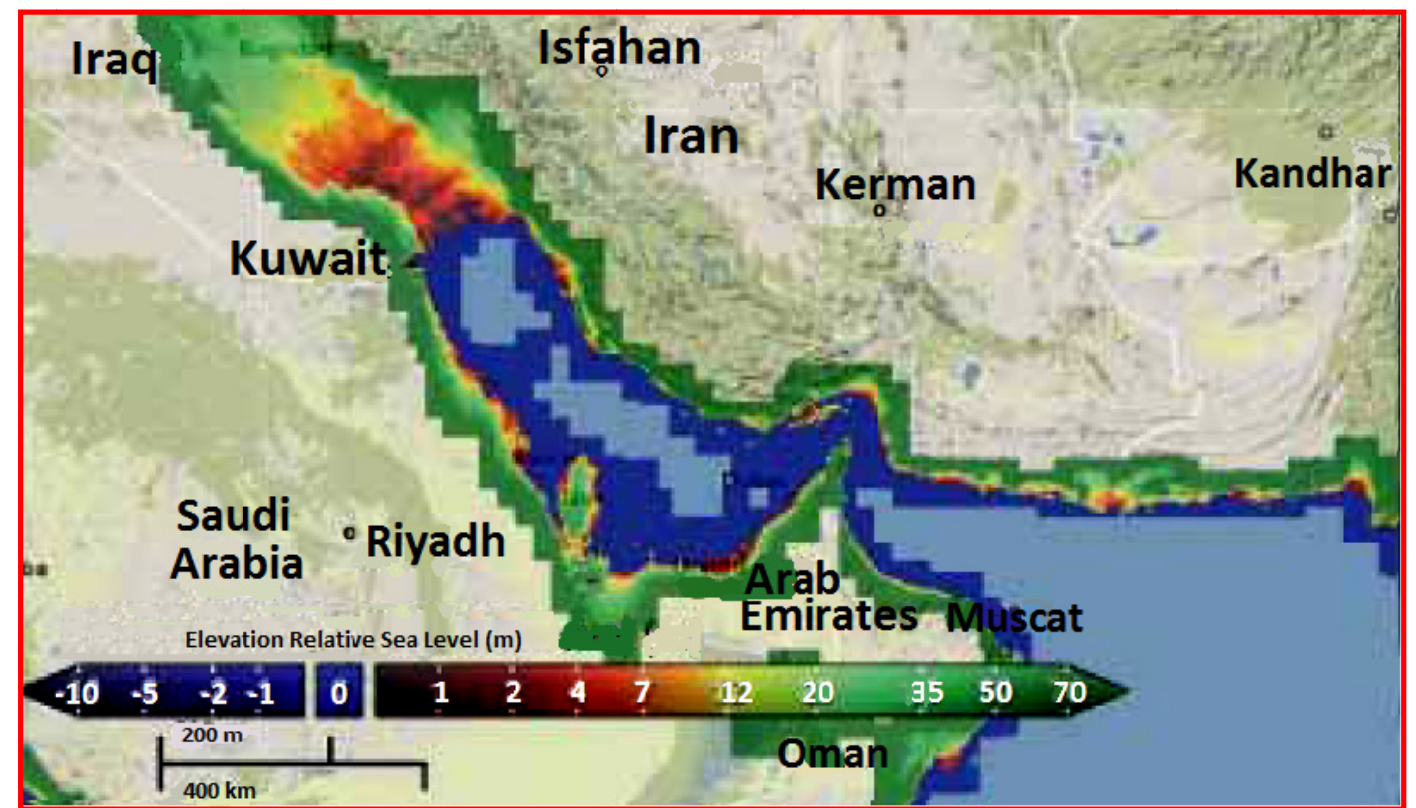

Fig. 9 Effect of sea level rise on Iraq and Kuwait [35]. 
Table 1 Impacts of sea level rise: Middle East and North Africa region [34].

\begin{tabular}{|c|c|c|c|c|c|}
\hline Details & $1 \mathrm{~m}$ & $2 \mathrm{~m}$ & $3 \mathrm{~m}$ & $4 \mathrm{~m}$ & $5 \mathrm{~m}$ \\
\hline \multicolumn{6}{|c|}{ Area $\left(\right.$ total $\left.=10,050,556 \mathrm{~km}^{2}\right)$} \\
\hline Impacted area & 24,654 & 33,864 & 43,727 & 53,615 & 63,120 \\
\hline Percent of total area & 0.25 & 0.34 & 0.44 & 0.53 & 0.63 \\
\hline \multicolumn{6}{|c|}{ Population (total $=259,396,000)$} \\
\hline Impacted population & $8,307,472$ & $10,912,744$ & $13,684,993$ & $16,454,655$ & $19,439,678$ \\
\hline Percent of total population & 3.20 & 4.21 & 5.28 & 6.34 & 7.49 \\
\hline \multicolumn{6}{|c|}{ Urban extent $\left(\right.$ total $\left.=190,030 \mathrm{~km}^{2}\right)$} \\
\hline Impacted area & 3,679 & 5,037 & 6,529 & 7,951 & 9,384 \\
\hline Percent of total area & 1.94 & 2.65 & 3.44 & 4.18 & 4.94 \\
\hline \multicolumn{6}{|c|}{ Agricultural extent $\left(\right.$ total $\left.=354,294 \mathrm{~km}^{2}\right)$} \\
\hline Impacted area & 4,086 & 6,031 & 8,007 & 9,819 & 11,451 \\
\hline Percent of total area & 1.15 & 1.70 & 2.26 & 2.77 & 3.23 \\
\hline \multicolumn{6}{|c|}{ Wetlands area $\left(\right.$ total $\left.=342,185 \mathrm{~km}^{2}\right)$} \\
\hline Impacted area & 11,361 & 14,758 & 18,224 & 21,417 & 24,277 \\
\hline Percent of total area & 3.32 & 4.31 & 5.33 & 6.26 & 7.09 \\
\hline
\end{tabular}

\subsection{The Impact of Freshwater Sources}

IPCC [5] stated that the global temperature could be increased by $3{ }^{\circ} \mathrm{C}$ by the $2050 \mathrm{~s}$, if socio-economic development continues to follow existing trends. One of the negative impacts of increased temperature is that it will modify the precipitation patterns leading to extreme events which will affect the availability of water resources particularly in tropical and Mediterranean areas [36, 37]. In most of the MENA countries the water demand had exceeded the available water resources which adversely affect the social and economic development [38].

Most of the MENA water resources are characterized by low and limited amount. Fig. 10 shows that MENA countries can be divided into three categories. The first includes Iraq, Sudan and Egypt which have annual water resources of 75,65 and 58 billion $\mathrm{m}^{3} /$ year, respectively. The second includes Algeria, Lebanon, Mauritania, Morocco, Somalia, Syria, Tunisia and Yemen with total water resources of 5-30 billion $\mathrm{m}^{3} /$ year. The remainder has water resources of less than 5 billion $\mathrm{m}^{3} /$ year.

Total annual groundwater resources in the MENA region are about 35 billion $\mathrm{m}^{3}[2,13]$.

The combination of the climatic change impact and rapid trends of population growth, FAO projections indicated that Algeria, Egypt, Morocco, Syria and Tunisia are expected to experience severe water shortages by 2050 , and only Iraq is expected to be in a relatively better situation [31].

It should be mentioned however that Iraq is recently suffering from reduction in the flow rates of the Tigris and Euphrates Rivers due to building of huge dams in Turkey and Syria $[11,16]$. However, the water demand is rapidly increasing for all the MENA countries while water supply is decreasing.

Climatic change is projected to increase the salinity levels of ground water as a result of increased temperature. Furthermore, due to climatic change conditions the watersheds may face serious soil erosion and desertification [21].

Recent studies conclude that there are many negative impacts of climatic change on freshwater systems represented by increases in temperature, evaporation, sea level and precipitation variability [7].

The current studies projected that, by the end of the 21 st century, the flow of rivers located high latitude is to be increased while it will be decreasing in the Middle East, Europe and Central America. However, the magnitude of these changes is highly uncertain [40].

\subsection{The Impact of Increasing Drought}

Drought is one of the big problems facing the MENA 


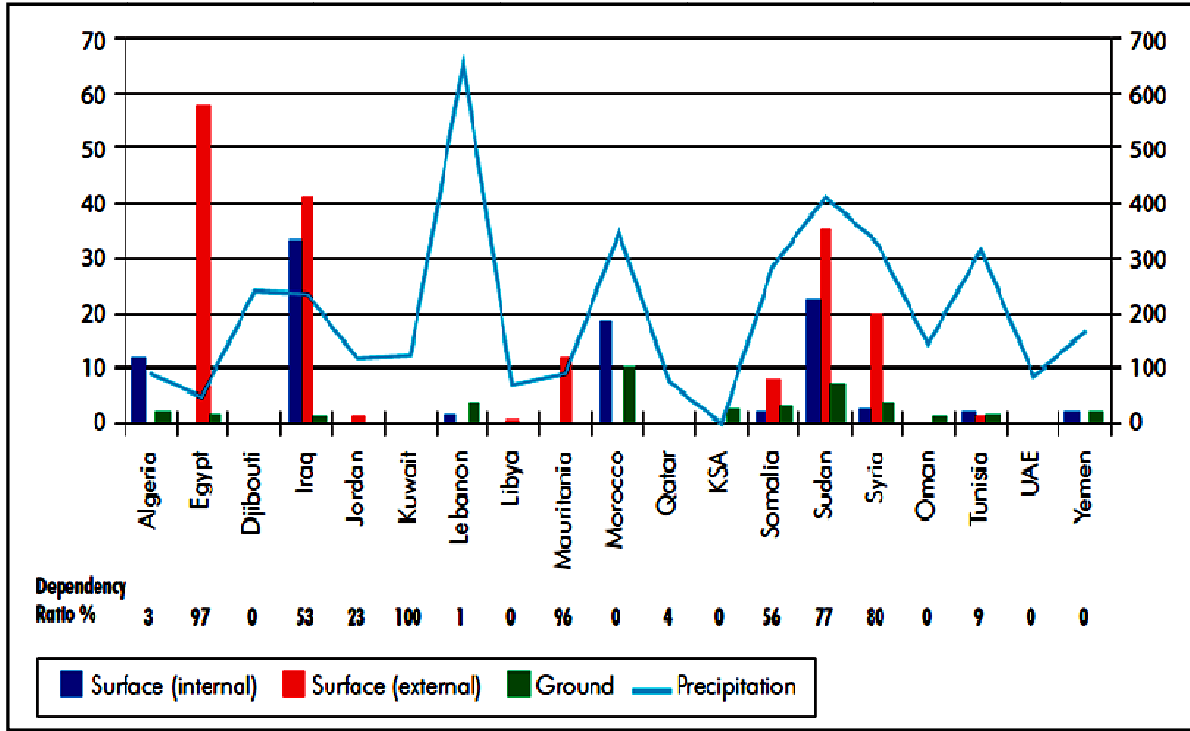

Fig. 10 The situation of the water resource for MENA countries [39].

region currently and in the future. The drought, from climatic point of view, defined as temporary reduction in water or moisture availability significantly below the normal or expected amount for specified period. From hydrological point of view, drought can define as: "a period of abnormally dry weather sufficiently prolonged for the lack of precipitation to caus a serious hydrological imbalance, carrying connotation for moisture deficiency with respect to man's usage of water [41]."

Wetherald and Manabe [42] stated that the risk of both floods and droughts will increase due to warm climate with increased variability.

The drought will affect the agricultural life and water supply in the MENA region [2]. This is due to the fact, that most of the agricultural area of MENA region is rain-fed [43]. For example, about one-third of Iraq's cereal production (wheat and barley) is produced under rain-fed conditions in the north of Iraq [19].

It is expected that drought events are to increase in future as a result of climatic change [44].

During the last 30 years, drought frequency increased in Morocco, Tunisia, Algeria and Syria, for example in Morocco, the drought increased from one event every 5 year period before 1990, to one event every 2 year period [45-47]. Drought is also a recurring event in the Near East. The recent droughts in Jordan and Syria were the worst ever recorded in recent decades [31]. Wetherald and Manabe [42], stated that, due to the increase of global temperature, the risk of both floods and droughts will be increased.

\subsection{The Impact of Dust Storms}

Dust storms may lead to aerosol pollution which change cloud properties and then reduce precipitation in the polluted region. In the desert land, the limited precipitation will help to produce more dry soil which leads to produce more dust in the air (Fig. 11) [48].

AL-Bayati [28] indicated that there are 11 factors effecting the frequency of dust storms phenomenon in Iraq, the most important factor was relative humidity while evaporation and clouds quantity were the least effective.

AFED [20] reported that due to the continuous emissions in the atmosphere from unregulated industrial emissions, many desert regions will get hotter and drier in a phenomenon called the amplification effect, that is, already hot and dry places on Earth will become even more so. Consequently, dust storms in the desert will become more frequent and intense. 


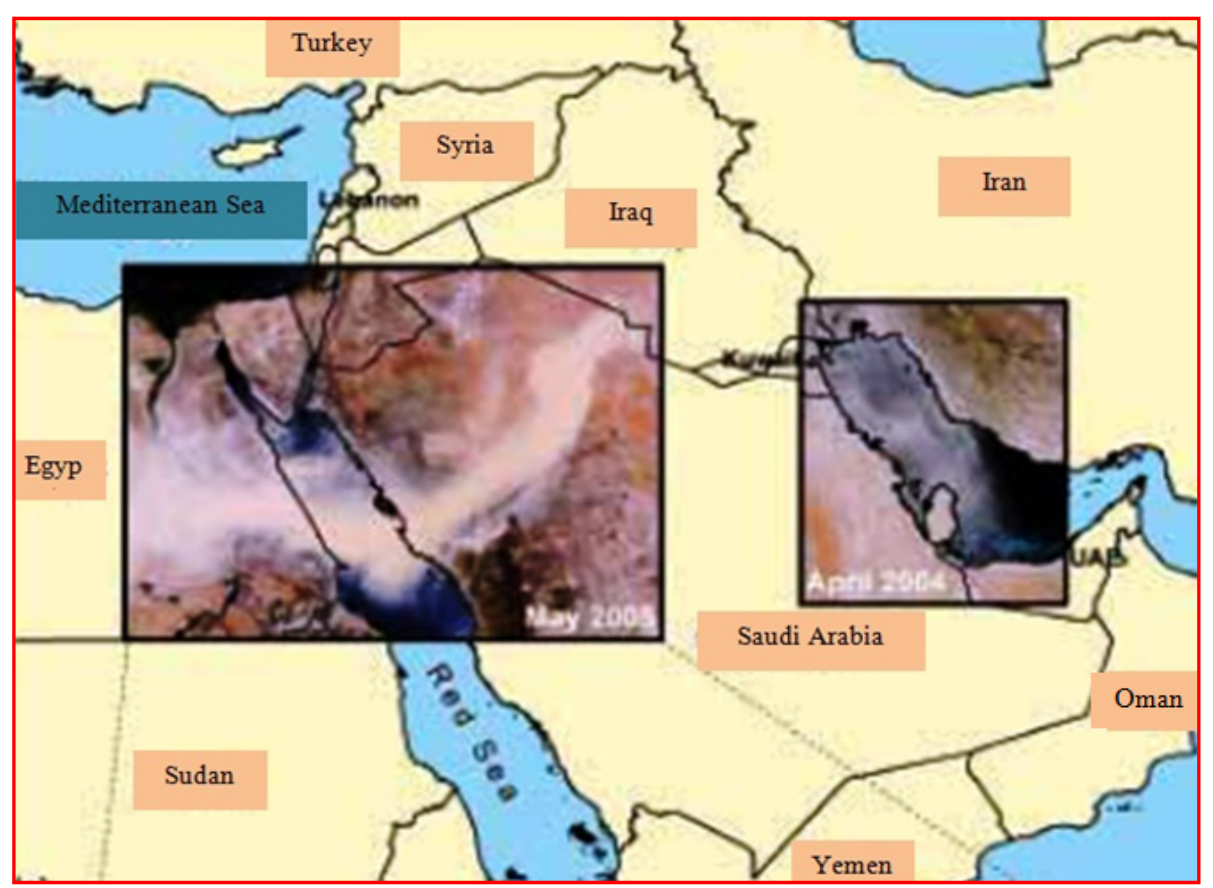

Fig. 11 A thick dust moving from southwest of Iraq passing Saudi Arabia and then the Red Sea to reach Egypt, MODIS-Aqua images, May 2005 [33].

\subsection{The Impact on Human Life}

High temperature adversely affect human life mainly due to changes in geographical ranges of disease vectors like mosquitoes, waterborne pathogens, water quality, air quality and food availability and quality. Higher $\mathrm{CO}_{2}$ concentrations and fiercer and more frequent sand storms in desert areas will increase allergic reactions and pulmonary diseases all over the region [5].

Elasha [13] summarized the projected climatic change impacts on the MENA region depending on the IPCC assessment and related technical papers, by dividing the MENA region into three parts: MENA, Sub-Saharan Countries (Djibouti, Somalia, and Sudan) and States of the GCC (Gulf Cooperation Council) as follows:

The mean temperatures of MENA region is projected to increase $3{ }^{\circ} \mathrm{C}$ to $5{ }^{\circ} \mathrm{C}$ while the precipitation is to decrease about $20 \%$ [5], which lead to reduction in water runoff by $20 \%$ to $30 \%$ in most of MENA region by 2050 [37], and thus the influence moves to water supply that might be reduced by $10 \%$ or greater by 2050 . The weather events will include more droughts and floods. Mediterranean sea water level is predicted to rise between $30 \mathrm{~cm}$ and $1 \mathrm{~m}$ by the end of the century causing flooding of coastal areas along the Nile Delta [5].

Warmer temperatures and more variable rainfall are predicted by climatic models in Sub-Saharan Countries (Djibouti, Somalia and Sudan) which may lead to more rapid desertification, droughts, food shortages and famines. On the other hand, the human health will be affected by warmer climate, some disease will be more active like malaria, yellow fever, dengue fever and other vector-borne. Freshwater deficit problem will worsen.

Rising both of temperature and sea level will affect the states of the GCC (Gulf Cooperation Council) region as follows: increase the salinity of underground water, more land degradation will occur, biodiversity on land and in the Gulf will be affected, as well as coastlines and marine life severely and could impact desalination plants that are the source of water for the GCC region [13]. 


\section{Adaptation and Mitigation for Climatic Change}

The IPCC [29] defines adaptation as any "adjustment in natural or human systems in response to actual or expected climatic stimuli or their effects, which moderates harm or exploits beneficial opportunities".

Vulnerability is defined by the IPCC [5], as "degree to which a system is susceptible to, or unable to cope with, adverse effects of climatic change, including climatic variability and extremes".

There is a wide range of adaptation that is available and possible to be followed by the world nations in order to reduce vulnerability to climatic change.

Part of these adaptation options that can be implemented in some sectors at low cost, and/or with high benefit-cost ratios, sectors like water, agriculture, infrastructure/settlement (including coastal zones), human health, tourism, transport and energy. There is high agreement and much evidence of substantial economic potential for the mitigation of global GHG emissions over the coming decades that could offset the projected growth of global emissions or reduce emissions below current levels [5].

MENA countries will have to play their role according to the mitigation efforts within international action, they can adopt development of clean energy technologies, specifically solar, wind and hydro. As an example of projects in MENA countries that serve the climatic change mitigation efforts topic like in Egypt wind energy, the introduction of CNG (compressed natural gas) as a transport fuel, the solar power projects, in Palestine, Tunisia, Morocco and Algeria. In the UAE, the massive forestation program, zero-carbon city in $\mathrm{Abu}$ Dhabi, in Algeria, the pioneering carbon capture.

However, the current capacities and actions are inadequate, most of the above are partially projects that need support by MENA governments in a unified plan to be circulated to various MENA countries.

\section{Background of Climatic model CGCM3.1(T47)2}

There are several GCMs (global climatic models) as a research tool, to simulate the climatic change [5]. These GCMs have been developed by different research groups and organizations over the years. The output of all has been made available through the IPCC and its data distribution centre.

SRES (special report on emissions scenarios) is a report by the IPCC (2000), which contains six models dealing with climatic changes. The models contain different scenarios (A1FI, A1B, A1T, A2, B1 and B2). The SRES scenarios were used in the third and fourth assessment IPCC reports, they known as (TAR) and (AR4), where published in 2001 and 2007 respectively. IPCC did not provide any diagnosis about which scenario is better or more accurate for the future emission guess.

The emissions scenario that are used in this work is (A2) which is a case of rapid and successful economic development, in which regional average income per capita converge current distinctions between "poor" and "rich" countries eventually dissolve. The A2 scenarios are of a more divided world than other scenarios and characterized by: 1/A world of independently operating, self-reliant nations, $2 /$ continuously increasing population and $3 /$ regionally oriented economic development.

The dataset was produced by the CRU (CLIMATIC RESEARCH UNIT) of UEA (University of East Anglia), and reformatted by IWMI (International Water Management Institute) [24].

CRU prepared a dataset of mean monthly surface data (for 1901-2002) over global land areas, for a range of variables: precipitation and wet-day frequency, mean, maximum and minimum temperature and diurnal temperature range, vapor pressure, percent cloud cover and ground-frost frequency.

The time periods for the historical scenarios in the CGCM3.1(T47)2 model are across the following periods: $1900-1930,1930-1960,1960-1990$ and 
1990-2009. While the time periods for the future scenarios are across the following periods: 2020-2039, 2040-2059, 2060-2079 and 2080-2099.

The main description of the model is as follows:

- Model ID: cccma_cgem3_1, Originating Group(s): Canadian Centre for Climatic Modeling \& Analysis, Country: Canada, CMIP3 ID: CGCM3.1 (T47)2, Primary Reference: Flato and Boer, 2001;

- The model CGCM3.1 (T47) with A2 scenario was chosen in order to simulate the average monthly temperature and rainfall on Iraq for the historical period 1900-2009, and for mean projected temperature and rainfall till the period 2099 .

\section{Discussion}

The historical period covered 1900-2009, was divided to four sub-periods as follow: first 1900-1930, second 1930-1960, third 1960-1990 and fourth 1990-2009. The future period covered (2020-2099), was also divided into four sub-periods as follow: first 2020-2039, second 2040-2059, third 2060-2079 and fourth 2080-2099.

\subsection{Historical Temperature Change (1900-2009)}

Fig. 12 shows the change of average monthly temperature for the four above periods on Iraq. A simple comparison for the temperature data indicates that the average monthly temperature for the four periods fluctuated between the lowest and highest value as follows: 9.2-32.9, 10.3-32.7, 9.3-32.8 and 8.6-33.9 $\left({ }^{\circ} \mathrm{C}\right)$ within the four periods, respectively.

The first period represents the temperature benchmark for all periods, the comparison for the first and second period indicates that the average monthly temperature for the following six months January, April, July, September, October and December during the second sub-period increased. For these months, the average monthly temperature tend to increase by 0.8 , $0.4,0.4,0.5,1.2$ and $1.1\left({ }^{\circ} \mathrm{C}\right)$, respectively. Only two consecutive months had been increased in temperature (September and October), while in August and May there was no increase in temperature. During the remaining four months, i.e., February, March, June and November the temperature was decreasing by a range of 0.4-1.3 $\left({ }^{\circ} \mathrm{C}\right)$.

The comparison for the first and third sub-periods shows that, the third sub-period has increased in temperature just in five months (January April, August, October and December) by 1.8, 2.1, 0.2, 1.0 and 0.1 $\left({ }^{\circ} \mathrm{C}\right)$, respectively. No consecutive months had been increased in temperature in third sub-period.

What distinguishes the comparison of the first and

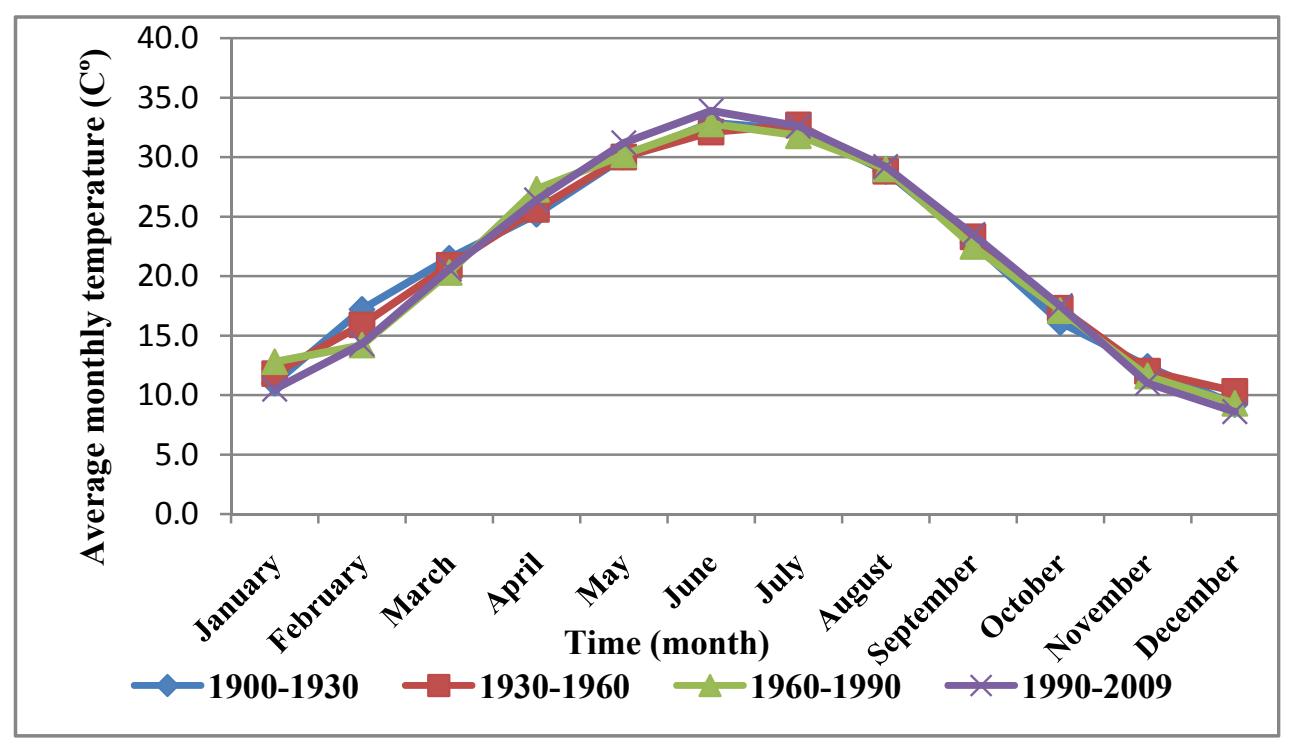

Fig. 12 Change of average monthly temperature for the period 1900-2009 in Iraq. 
fourth sub-periods is that the increase in temperature has taken place during consecutive months starting in April and continues until the end of the October with an increase in temperature which reached up to $1.2,1.2$, $1.0,0.3,0.4,0.7$ and 1.4 for these months, respectively. It seems that the distribution of increase in temperature differed and took new trend sequentially through these months.

Fig. 13 shows the average monthly temperature over the period 1900-2009, where maximum average monthly temperature reached up to $32.93\left({ }^{\circ} \mathrm{C}\right)$ during June and minimum average monthly temperature reached up to $9.35\left({ }^{\circ} \mathrm{C}\right)$ during December.

\subsection{Historical Rainfall Change (1900-2009)}

Fig. 14 shows the change of average monthly rainfall for the four sub-periods 1990-2009 on Iraq. In general, the rainfall kept on the same distribution during the past 109 years, with decline index of amount. A simple comparison for the rainfall data (Fig. 14) for the four periods shows that during January-March (first three months of the year) for the four above-mentioned sub-periods, the average monthly of rainfall fluctuated between the lowest and highest value of $21.3 \mathrm{~mm}$ and $37.6 \mathrm{~mm}$ with an average that reached up to $26.51 \mathrm{~mm}$.

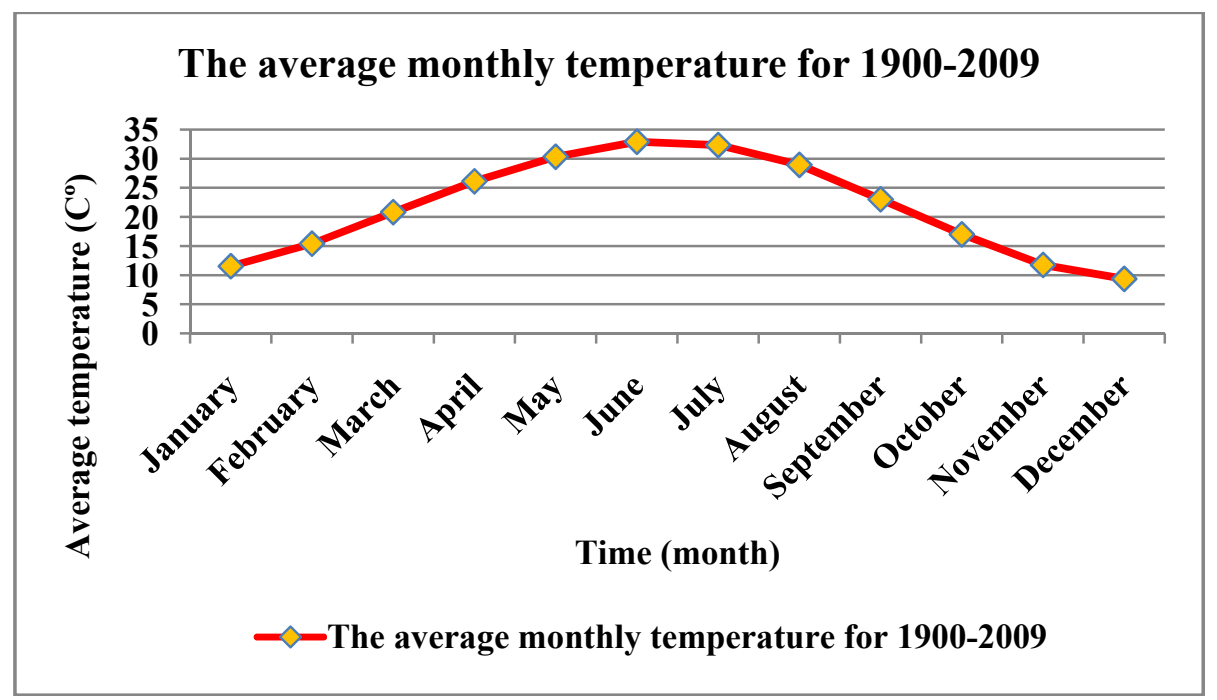

Fig. 13 Average monthly temperature over 109 years (1900-2009).

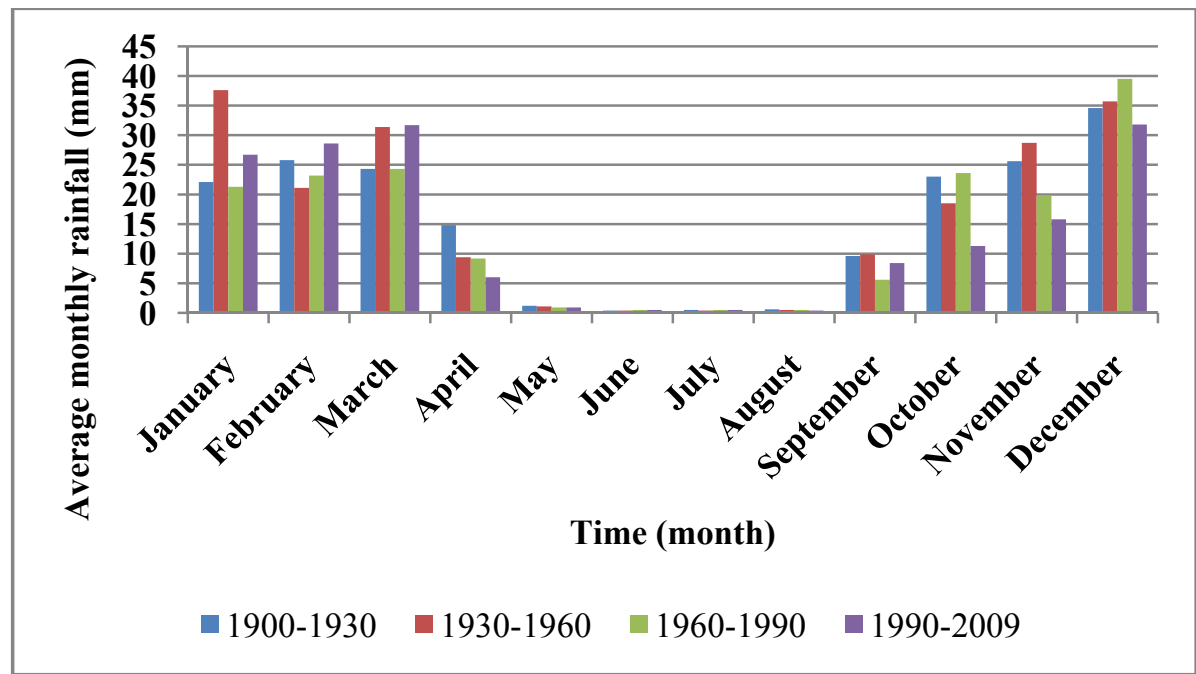

Fig. 14 The change of average monthly rainfall for the period 1990-2009 in Iraq. 
During April, the rainfall starts to decrease where April represent mid spring season of low rainfall in Iraq. For this month, the lowest and highest value of the average monthly rainfall fluctuate between $6.0 \mathrm{~mm}$ and $14.8 \mathrm{~mm}$ representing a clear indication of severe rainfall decrease. For the period May till August, the average monthly rainfall fluctuates between 0.4-1.2 $\mathrm{mm}$ with average that reached up $0.82 \mathrm{~mm}$. During the last four months of the year (September to December), the rainfall increased, starting from September, which is the end of the dry season (summer), by low average monthly rainfall that was ranging from $5.6 \mathrm{~mm}$ to 9.9 $\mathrm{mm}$. The average monthly rainfall begin to increase starting from October to reach its climax in December, and on the whole, the average monthly of rainfall during October to December fluctuate between the lowest and highest value of (11.3-39.5) $\mathrm{mm}$ respectively with an average that reached $25.66 \mathrm{~mm}$.

Fig. 15 shows average monthly rainfall over 109 year. Rainfall fluctuated between the lowest and highest values of $0.45 \mathrm{~mm}$ (June) and $35.4 \mathrm{~mm}$ (December) respectively. These rainfall values for Iraq do not satisfy the requirements of successful economic cultivation of winter crops such as wheat and barley in the rain-fed farms according to FAO classification.

\subsection{Future Temperature Change (2020-2099)}

Fig. 16 shows the change of average monthly temperature for the future sub-periods of 2020-2039, 2040-2059, 2060-2079 and 2080-2099 in Iraq. The months January, April, July and October represent mid-seasons for winter, spring, summer and autumn respectively in Iraq. A comparison for the temperatures during the mid-seasons during the four sub-periods shows that the difference in temperature between the second and first periods reached up to $0.94,1.86,1.4$ and $0.96\left({ }^{\circ} \mathrm{C}\right)$ which gives an indication that the reason of reduction in temperature during movement from first to second sub-period. The values of difference in temperature increased during the comparison between third and first sub-periods that reached up 1.97, 2.93, 2.9 and $2.27\left({ }^{\circ} \mathrm{C}\right)$. The maximum difference in temperature appeared during the comparison between fourth and first sub-periods that reached up to 3.26 , $4.28,4.51$ and $4.1\left({ }^{\circ} \mathrm{C}\right)$.

Giving a clear impression that the future portends a higher temperature, certainly the reflection of that will be on the overall facilities of environment.

Fig. 17 shows the future average monthly temperature over the period 2020-2099, where the maximum average monthly temperature reached up to $37.41\left({ }^{\circ} \mathrm{C}\right)$ during June and minimum average monthly temperature reached up to $4.24\left({ }^{\circ} \mathrm{C}\right)$ during January.

\subsection{Future Rainfall Change (2020-2099)}

Fig. 18 shows the change of average monthly rainfall for the future sub-periods of 2020-2039, 2040-2059, 2060-2079 and 2080-2099 in Iraq.

During January-March for the four sub-periods, the average monthly of rainfall fluctuated between the lowest and highest value of $12.91 \mathrm{~mm}$ and $20.63 \mathrm{~mm}$ with an average that reached $16.84 \mathrm{~mm}$ which represent a reduction percentage of about $36.47 \%$ relative to the historical record of rainfall for the same months. During the month of April, the rainfall increased in amount, the lowest and highest value of the average monthly rainfall fluctuates between 18.26 $\mathrm{mm}$ and $27.44 \mathrm{~mm}$ with average of $22.25 \mathrm{~mm}$ while was $9.85 \mathrm{~mm}$ in the historical records.

For the May till August, the average monthly rainfall fluctuates between $0.05-26.92 \mathrm{~mm}$ with average that reached $6.84 \mathrm{~mm}$, representing a significant increase compared with its value for the historical record $(0.82$ $\mathrm{mm})$.

During the last four months of the year (September-December), the average monthly rainfall $(0.13-0.81 \mathrm{~mm})$ significantly decreased relative to the historical period of record (5.6-9.6 mm).

The average monthly rainfall begin to increase starting 


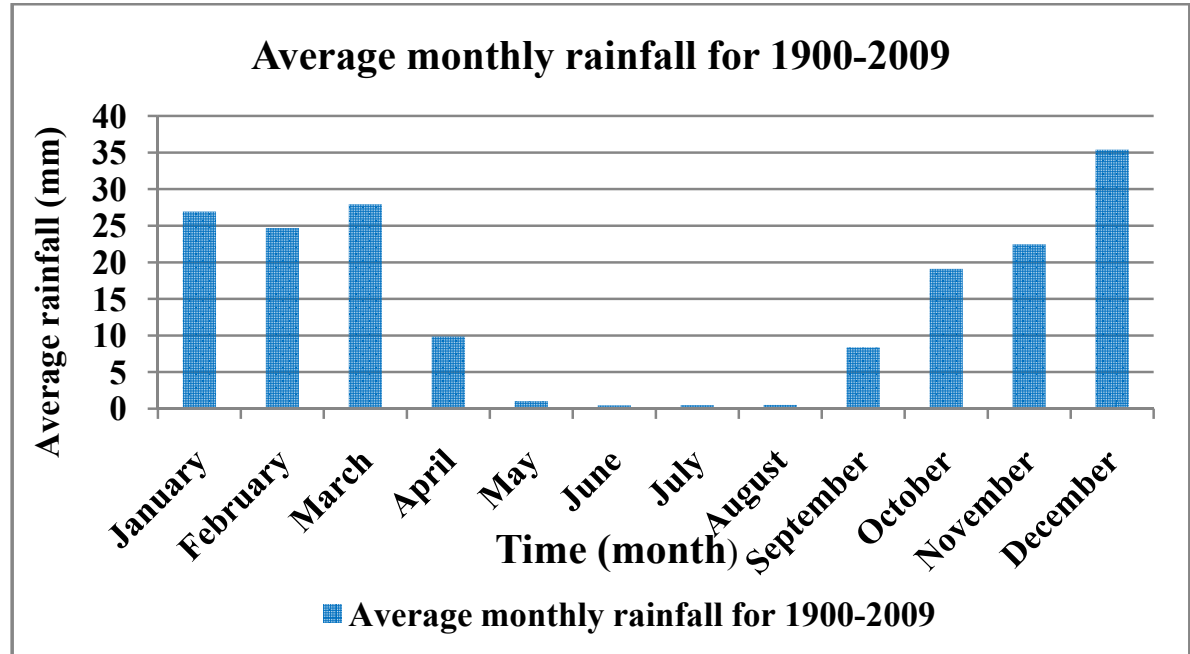

Fig. 15 Average monthly rainfall over 109 year (1900-2009).

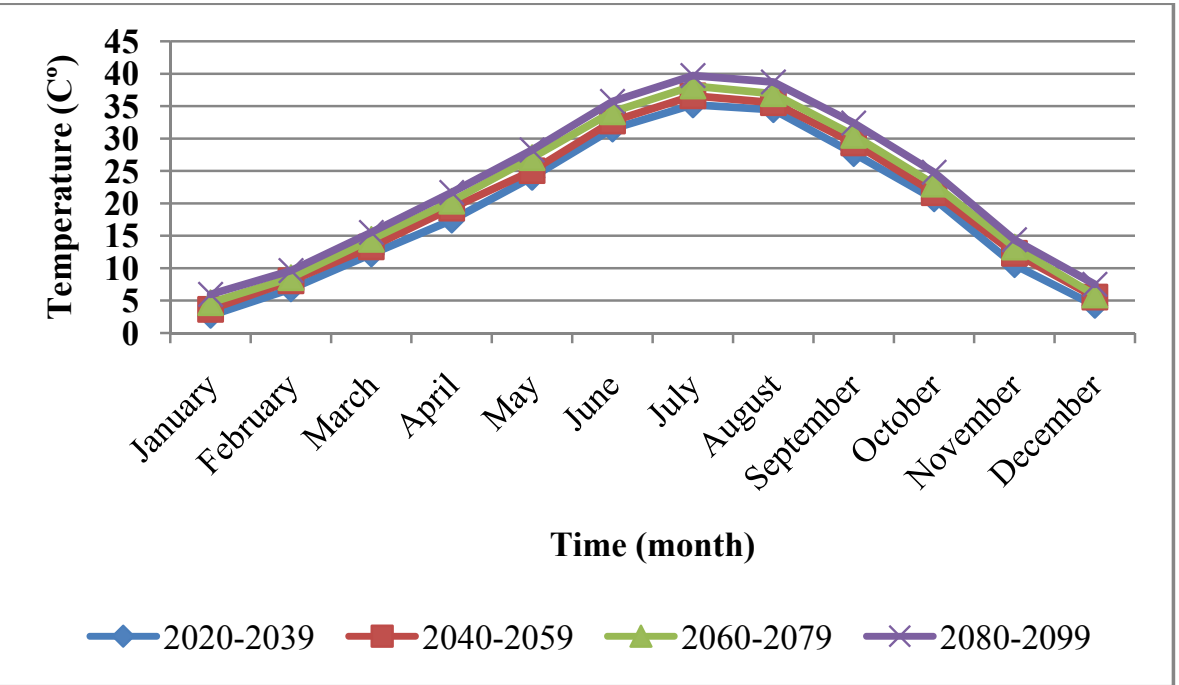

Fig. 16 The change of average monthly temperature for the period 2020-2099 in Iraq.

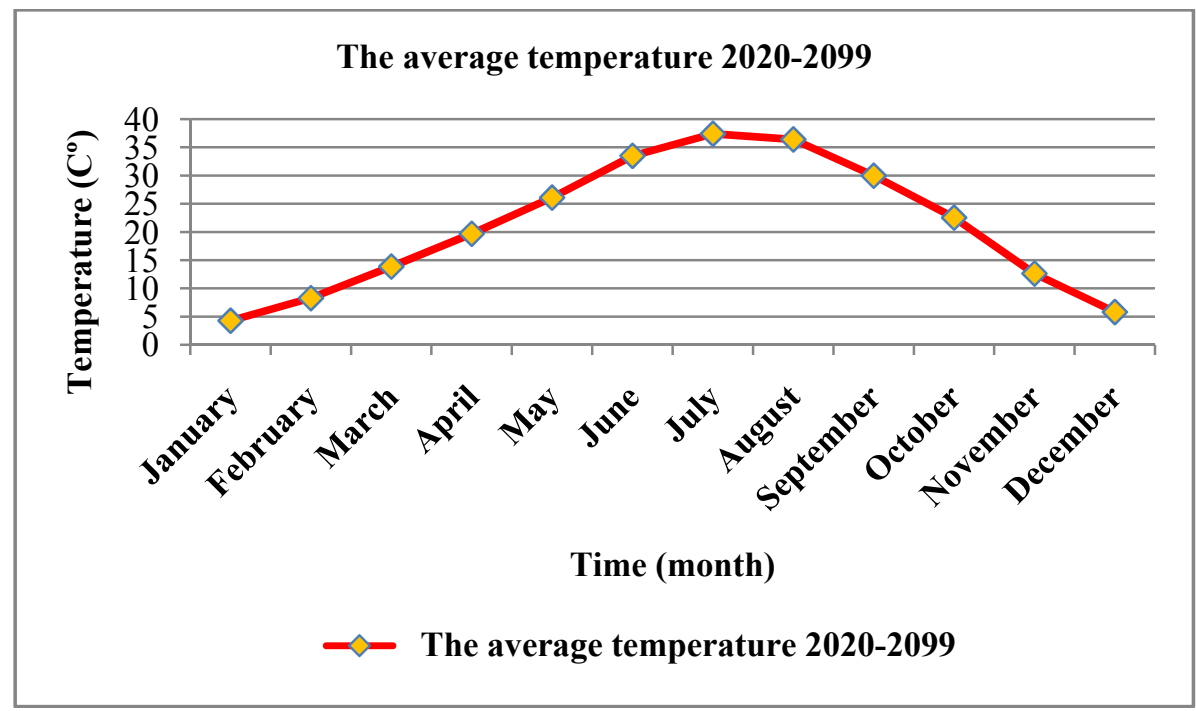

Fig. 17 Future average monthly temperature for the period 2020-2099. 


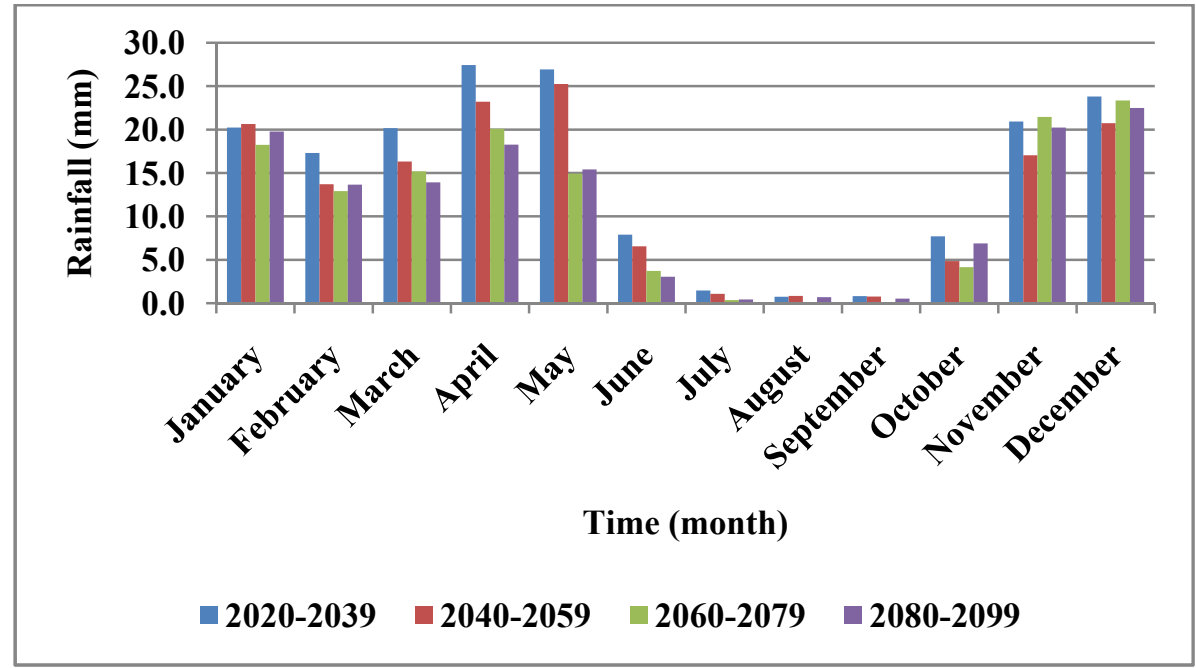

Fig. 18 The change of average monthly rainfall for the period 2020-2099 in Iraq.

from October to reach its climax in December (4.16-23.80 $\mathrm{mm}$ ) with average that reaches up to 16.13 mm representing significant decrease compared with the historical period record $(25.66 \mathrm{~mm})$.

Fig. 19 shows that the average monthly rainfall over the years 2020-2099 is fluctuated from $0.55 \mathrm{~mm}$ (September) to $22.59 \mathrm{~mm}$ (December), that indicate a clear further limitation of future rainfall on Iraq.

\subsection{The Average Temperature and Rainfall in Iraq}

Fig. 20 shows the distribution of average temperature for each of considered period over the period 1900-2099.

The annual temperatures reached 21.62, 21.73,
21.58 and $21.61\left({ }^{\circ} \mathrm{C}\right)$ for the historical sub-periods of the 1900-1930, 1930-1960, 1960-1990 and 1990-2009, respectively. For the future sub-periods of 2020-2039, 2040-2059, 2060-2079 and 2080-2099, it reached $18.94,20.24,21.39$ and $22.85\left({ }^{\circ} \mathrm{C}\right)$, respectively.

A comparison between these values shows that the increase of annual temperature was limited during the historical period 1900-2009, but it was relatively more significant during the future period 2020-2099. In general, the above is in agreement with the global worming that most models considered including the used model of CGCM3.1 (T47).

Fig. 21 shows that an increase and decrease of average annual rainfall, over both the historical and

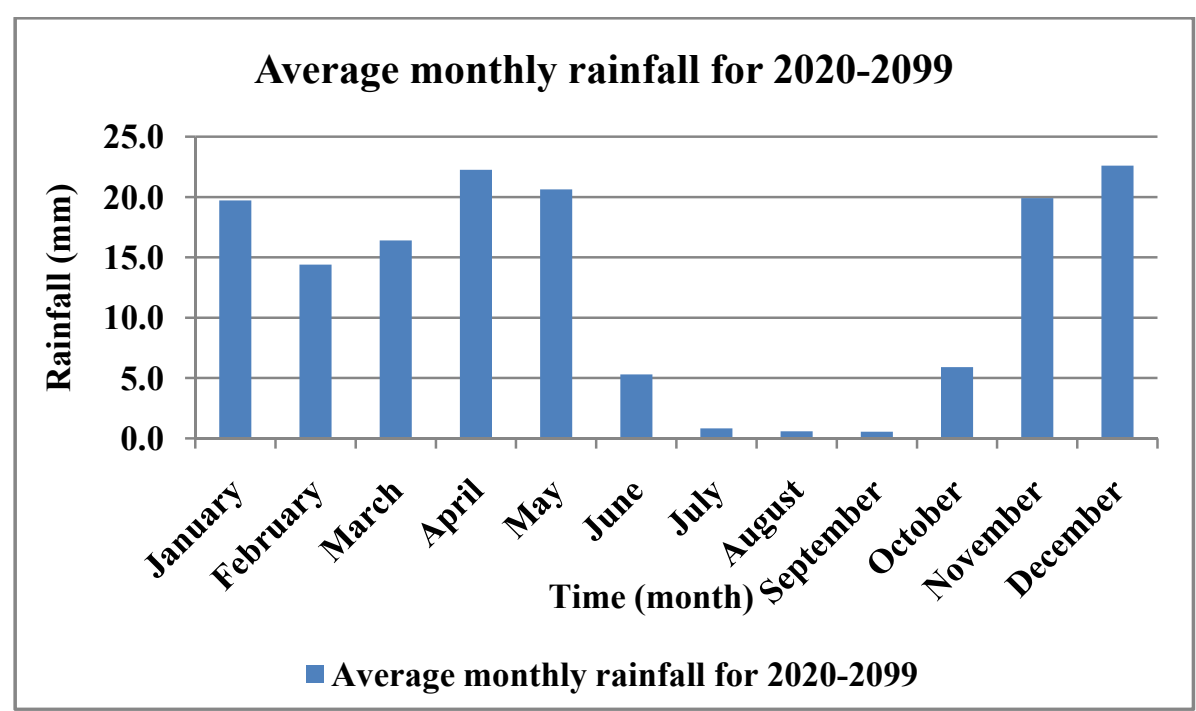

Fig. 19 Average monthly rainfall for the period 2020-2099 in Iraq. 


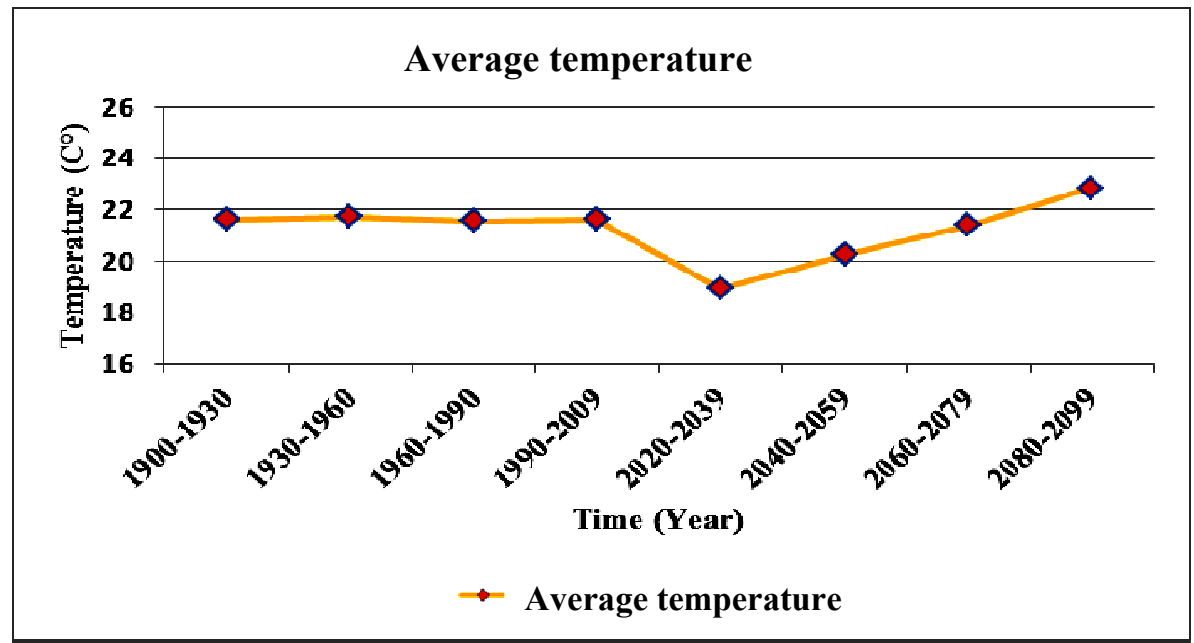

Fig. 20 Average annual temperature over the historical and future study periods.

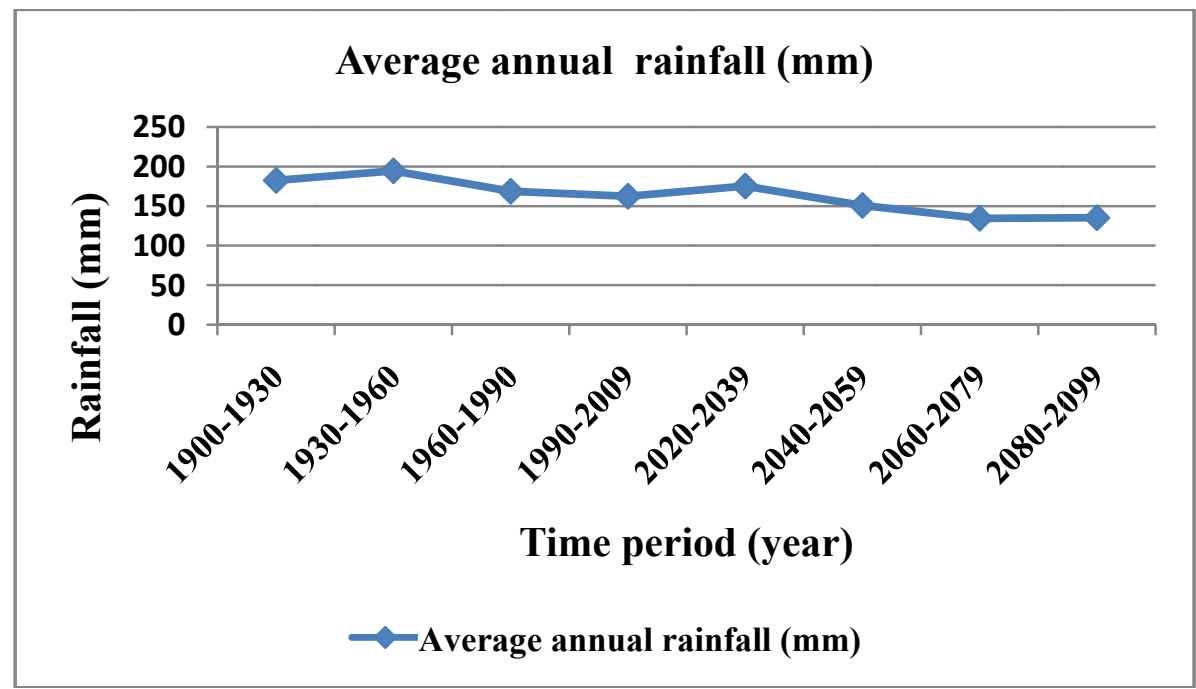

Fig. 21 Average annual rainfall ( $\mathrm{mm})$ over the study historical and future periods.

future study periods. The average annual rainfall for the four historical sub-periods was $182.5,194.7,168.9$ and $162.6 \mathrm{~mm}$, respectively. Comparing the first and the second sub-periods, the total rainfall value showed an increase of $12.2 \mathrm{~mm}$. The percentage increase reached up $6.68 \%$. Moving from the second to the third sub-periods the total rainfall decreased by $25.8 \mathrm{~mm}$, with a percentage decrease that reached $13.25 \%$. From the third to the fourth sub-periods the total rainfall fell again by $6.3 \mathrm{~mm}$, with a percentage decrease that reached $3.73 \%$.

The average annual of the rainfall was falling down from $194.7 \mathrm{~mm}$ during the period of 1930-1960 to reach its lowest value of $162.6 \mathrm{~mm}$ during 1990-2009.
It should be noted that the total summation of rainfall (average annual) has toned down its tendency when moving from third to fourth sub-periods.

The right part of Fig. 21 shows an increase and decrease of the average annual of the rainfall through the four sub-periods of 2020-2039, 2040-2059, 2060-2079 and 2080-2099 in Iraq.

The average annual rainfall for the four sub-periods, were $175.41 \mathrm{~mm}, 150.96 \mathrm{~mm}, 134.59 \mathrm{~mm}$ and 135.31 $\mathrm{mm}$, respectively. The value of total rainfall was reduced over time. Considering the average annual rainfall of the first future sub-period (2020-2039) where it can represents the rainfall benchmark for all future periods, the differences in total rainfall over the 
four sub-periods reached 24.45, 16.37 and then increased by $0.72 \mathrm{~mm}$, respectively. The percentage of reduction reached up to $13.93 \%, 10.83 \%$ and then increased by $0.53 \%$. In general, the average annual rainfall tends to reduce its values.

\section{Conclusions}

Most recent studies conclude that wide adaptation is required to reduce vulnerability to climatic change, a large array of mitigation options is projected to be available at least by 2030 .

Developing the scientific ability in different fields related to climatic change should be a top priority, ensuring political and financial support for the implementation of adaptation strategies. Increasing public awareness is very important about the impacts of climatic change on the environment and human health. The goal should be a clean technology to reduce emissions MENA region.

Higher temperatures and less rainfall will make the MENA countries more arid. These changes will have a series of effects, particularly on agriculture especially in rain-fed areas, energy, food security and contribute to malnutrition, famine and starvation.

Immediate actions should be taken in order to strengthen the adaptive capacity and reduce the vulnerability of sensitive sectors and systems to climatic change.

A wide of strategic policy measures will be required for adaptation, it is important to focus on modernization of methods for agricultural sector as well as enhance food security, expansions in manufacturing and service industries in rural areas.

The temperature of the world has increased and will continue to increase over the coming decades coupled with a decrease in rainfall as shown by CGCM3.1 (T47) model.

MENA countries must adopt a unified position to confront the challenge of climatic change and work with the international community in order to reduce the impact of climatic change.

\section{Acknowledgments}

The authors would like to express their sincere thanks to Professor Ian Foster of Northampton University, UK for his suggestions and help during the preparation of this paper. Thanks to Mrs. Semia Ben Ali Saadaoui of the UNESCO-Iraq for her encouragement and support.

The research presented has been financially supported by Luleå University of Technology, Sweden and by "Swedish Hydropower Centre-SVC" established by the Swedish Energy Agency, Elforsk and Svenska Kraftnät together with Luleå University of Technology, The Royal Institute of Technology, Chalmers University of Technology and Uppsala University. Their support is highly appreciated.

\section{References}

[1] K. Hailemariam, Impact of climate change on the water resources of Awash River Basin, Ethiopia, climate research, International and Ultidisciplinary Journal 12 (1999) 91-96.

[2] M. Medany, Impact of Climate Change on Arab Countries, Chapter 9, 2008, www.afedonline.org/ afedreport/english/book9 (accessed Jan. 1, 2013).

[3] IPCC, Climate change 2001: Synthesis report, in: R. Watson, the Core Writing Team (Eds.), Cambridge University Press, Cambridge, UK, 2001.

[4] United Nations Framework Convention on Climate Change, UNFCCC, Geneva, 1992.

[5] IPCC, Climate Change 2007: The Physical Science Basis, Cambridge University Press, Cambridge, 2007.

[6] IPCC, Emissions Scenarios Summary for Policymakers, 2000, http://www.ipcc.ch/pdf/special-reports/spm/sres-en.pdf (accessed Jan. 1, 2013).

[7] IPCC, Climate Change 2007: Climate Change Impacts, Adaptation and Vulnerability, Cambridge University Press, Geneva, 2007.

[8] Global Carbon-Dioxide Emissions Increase by $1.0 \mathrm{Gt}$ in 2011 to Record, IEA (International Energy Agency), 2012, http://www.iea.org/newsroomandevents/news/2012 /may/ name,27216, en.html (accessed May 30, 2012).

[9] NOAA, National Oceanic and Atmospheric Administration, Trends in atmospheric carbon dioxide, 2012, http://www.esrl.noaa.gov/gmd/ccgg/trends/global.html (accessed June 2, 2012).

[10] World Population Prospects: The 2008 Revision Population Data Base, UNDESA (United Nations 
Department of Economic and Social Affairs), 2009.

[11] N. Al-Ansari, S. Al-Oun, W. Hadad, S. Knutsson, Water loss in Mafraq Governorate, Jordan, Natural Science 5 (3) (2013) 333-340.

[12] A.A. Abahussain, S. Anwar, K. Al-Zubari, N. Alaa El-Deen, M. Abdul-Raheem, Desertification in the Arab Region: Analysis of current status and trends, Journal of Arid Environments 51 (2002) 521-545.

[13] B.O. Elasha, Mapping of Climatic Change Threats and Human development Impacts in the MENA Region, United Nations Development Programme, MENA Human Development Report (AHDR), Research Paper Series, 2010.

[14] The Arab Word, http://www.arabbay.com/arabmap.htm (accessed Jan. 1, 2013).

[15] FAO, Water Reports, 1997, pp. 1020-1203, http://www.fao.org/docrep/W4356E/W4356E00.htm (accessed Jan. 1, 2013).

[16] N. Al-Ansari, S. Knutsson, Toward prudent management of water resources in Iraq, J. Advanced Science and Engineering Research 1 (2011) 53-67.

[17] FAO, Arid Zone Forestry: A Guide for Field Technicians, 2003, http://www.fao.org/docrep/ T0122E/t0122e03.htm (accessed Jan. 1, 2013).

[18] T.M. Omer, Country Pasture/Forage Resource Profile, Iraq, FAO Organization, 2011, http://www.fao.org/ag/ AGP/AGPC/doc/Counprof/Iraq/Iraq.html (accessed Jan. 1, 2013).

[19] FAO, Irrigation in the Middle East Region in Figures, AQUASTAT Survey 2008, Water report 34, 2008.

[20] Impact of Climate Change on Arab Countries, AFED (Arab Forum for Environment and Development), 2009.

[21] L. Haas, Mediterranean Water Resources Planning and Climate Change Adaptation, Mediterranean Regional Roundtable, Athens, Greece, Dec. 10-11, 2002.

[22] S. Attaher, M.A. Medany, A.A. Abdel Aziz, A. El-Gindy, Irrigation-water demands under current and future climate conditions in Egypt, Misr. Journal of Agricultural Engineering 23 (4) (2006) 1077-1089.

[23] Y. Mohammed, Climate change impact assessment on soil water availability and crop yield in Anjeni watershed blue Nilebasin, Master Thesis, Arba Minch, Ethiopia, Aug. 2009.

[24] World Bank, DorteVerner and Mme. Fatma El-Mallah (League of Arab States), Adaptation to a Changing Climate in the Arab Countries MNA Flagship report, Sustainable Development Department, Middle East and North Africa Region, Oct. 2011.

[25] H. Al-Ani, Tariq, analytical study of some elements and variables of the climate at Iraq and surrounding areas, Master Thesis, College of Science, University of Al-Mustansiriya, 2001.
[26] J.Q. Yahya, Climate change for the semi-mountainous region in Iraq and its impact on the productivity of wheat and barley, Master Thesis, Department of Geography, University of Tikrit, College of Education, 2002.

[27] H. Al-Obeidi, H. Shit, The effect of climate extremism on the environment of the region's undulating, Doctoral Dissertation, Department of Geography, College of Education, University of Tikrit, 2004.

[28] F.F. Al-Bayati, Climatic conditions and their impact on the geographical distribution of the dust storms Empirical Study at Al-Anbar province-Iraq, Anbar University, Journal for the Humanities 1 (2011) 1-26.

[29] IPCC, Climate Change 2001: The Scientific Basis, Contribution of Working Group I to the IPCC Third Assessment Report Cambridge, Cambridge University Press, UK, 2001.

[30] WRI, Earth Trends Data Tables: Climate and Atmosphere, World Resources Institute, Washington D.C., 2005.

[31] FAO, The State of Food and Agriculture, Food and Agriculture Organization of the United Nations, Rome, 2002.

[32] Drylands, People, and Ecosystem Goods and Services: A Web-Based Geospatial Analysis, WRI (World Resources Institute), 2002.

[33] E. Ghoneim, Remote sensing study of some impacts of global warming on the Arab Region, in: M. Tolba, N. Saab (Eds.), Arab Environment Climate Change Report, The Arab Forum for Environment and Development (AFED), 2009, pp. 31-46.

[34] S. Dasgupta, B. Laplante, C. Meisner, J. Yan, The Impact of Sea Level Rise on Developing Countries: A Comparative Study, World Bank Policy Research Working Paper 4136, Feb. 2007.

[35] Middle East Sea Level Risks, Global Warming Art License, 2007.

[36] F. Giorgi, Climate Change Hotspots, Geophysical Research Letters 33, L08707, Implementation of Decision 1/CP.10 of the UNFCCC Convention, 2006.

[37] P.C.D. Milly, K.A. Dunne, A.V. Vecchia, Global patterns of trends in streamflow and water availability in a changing climate, Nature 438 (17) (2005) 347-350.

[38] C. Bao, C. Fang, Water resources constraint force on urbanization in water deficient regions: A case study of the Hexi Corridor, arid area of NW China, Ecological Economics 62 (2007) 508-517.

[39] FAO, AQUASTAT database, 2002, http://www.fao.org/ ag/agl/aglw/aquastat (accessed Jan. 1, 2013).

[40] N.W. Arnell, Climate change and global water resources: SRES scenarios and socio-economic scenarios, Global Environmental Change 14 (2004) 31-52.

[41] G. Rossi, An integrated approach to drought mitigation in Mediterranean Regions, in: Proceeding of Drought 
Mitigation for the Near East and Mediterranean Workshop, Syria, 2001.

[42] R.T. Wetherald, S. Manabe, Simulation of hydrologic changes associated with global warming, J. Geophys. Res. 107 (19) (2002) 43-79.

[43] T. Oweis, A. Hachum, Water harvesting and supplemental irrigation for improved water productivity of dry farming systems in West Asia and North Africa, New directions for a diverse planet, in: Proceedings of the 4th International Crop Science Congress, Brisbane, Australia, Sep. 26-Oct. $1,2004$.

[44] S. Nicholson, On the question of the recovery of the rains in the West African Sahel, J. Arid Environ. 63 (2005) 615-641.

[45] M. Karrou, Climatic change and drought mitigation: Case of Morocco, in: The First Technical Workshop of the
Mediterranean, Component of CLIMAGRI Project on Climate Change and Agriculture, Rome, Sep. 25-27, 2002.

[46] A. Abbas, Drought suppression procedures for dry lands, in: The First Technical Workshop of the Mediterranean, Component of CLIMAGRI Project on Climate Change and Agriculture, Rome, Sep. 25-27, 2002.

[47] R. Mougou, M. Mohsen, Hendi Zitoune Case Study: Agro climatic Characterization and Evapotranspiration Evolution in Climate Change Conditions, Contribution to the AIACC AF 90 North Africa Project: Assessment, Impacts, Adaptation, and Vulnerability to Climate Change on North Africa: Food and Water Resources, Fourth Tunisian semi-annual report, 2005.

[48] F. Rosenfeld, Y. Rudich, R. Lahav, Desert dust suppressing precipitation: A possible desertification feedback loop, Geophysics 98 (11) (2001) 5975-5980. 